\title{
Historic Fourth Ward Park, Phase 1 Methods
}

University of Georgia Research Assistant:

Rachael Shields, LEED Green Associate, 2019 MLA Candidate

University of Georgia Research Fellows:

Dr. Jon Calabria, Associate Professor

Brian Orland, Professor of Geodesign

Alfie Vick, Associate Professor

HDR Firm Liaisons:

David West, Senior Landscape Architect

Robert Bryant, Planning and Landscape Architecture Discipline Leader

This investigation was conducted as part of the Landscape Architecture Foundation's 2018 Case Study Investigation (CSI) program. CSI matches faculty-student research teams with design practitioners to document the benefits of exemplary high-performing landscape projects. Teams develop methods to quantify environmental, economic, and social benefits and produce Case Study Briefs for LAF's Landscape Performance Series.

To cite:

Shields, Rachael, Jon Calabria, Brian Orland, and Alfred Vick. "Historic Fourth Ward Park, Phase 1 Methods." The Landscape Performance Series. Landscape Architecture Foundation, 2018. https://doi.org/10.31353/cs1381

The full case study can be found at:

https://landscapeperformance.org/case-study-briefs/fourth-ward-park 


\section{Introduction}

Historic Fourth Ward Park is a stormwater park that helps mitigate stormwater runoff in the Old Fourth Ward neighborhood of Atlanta, Georgia. Although a more expensive underground vault system was originally proposed, the park has allowed many people to experience value of managing stormwater runoff in a novel way that contributes to additional benefits for community members such as a place to relax, walk their dog, jog, or watch the ducks. This research focuses on the first phase of a two-phase, 17-acre park, which was formerly a flood-prone brownfield. Researchers found that the park does indeed provide flood protection to the surrounding neighborhood. Through an intercept survey it was discovered that residents use the park more than twice per week as escape and relief from being indoors, come to walk, and are most attracted to the water. Economically the park has contributed to a significant increase in home values, property tax revenue, and occupied housing units.

\section{Acknowledgments}

We'd like to thank Dr. Roger C. Lowe III of UGA's Warnell School of Forestry and Natural Resources for taking the time to teach us about drone technology and capture imagery. It was a truly inspiring experience that might lead to a few remote pilot certificates! We'd also like to thank Kevin Burke of Atlanta BeltLine Inc., who provided a detailed background of the construction and maintenance of the park and fostered connections with stakeholders that wouldn't have been possible otherwise.

\section{Environmental Benefits}

- Reduces stormwater peak flow by $9.6 \%$, or 44 million gallons per day, in trunk sewer flows for a 10-year storm.

\section{Methods:}

The City of Atlanta was under a Consent Order to provide suitable capacity in their combined sewer and separated sanitary sewer service areas. Portions of the system experienced overflows during storms as small as a 5-year event (City of Atlanta Department of Watershed Management, HDR). Two ways to address the problem included: 1) increase the amount of capacity available by constructing additional vaults and conveyances, or 2) reduce the demand on the existing conveyances. The Clear Creek Basin has 350 acres that are directly connected to the park by surface, and another 500 acres are connected only via the sewer system (City of Atlanta Department of Watershed Management, HDR). Figure 1 shows the Clear Creek Basin and its relation to other nearby basins in the City of Atlanta. Figure 2 shows a detailed view of Clear Creek Basin's Sewer System in relation to the park. The City Program Management Team modeled stormwater impacts to determine the peak flow rate (InfoWorks) and installed 8 temporary flow meters throughout the area to refine the model. 


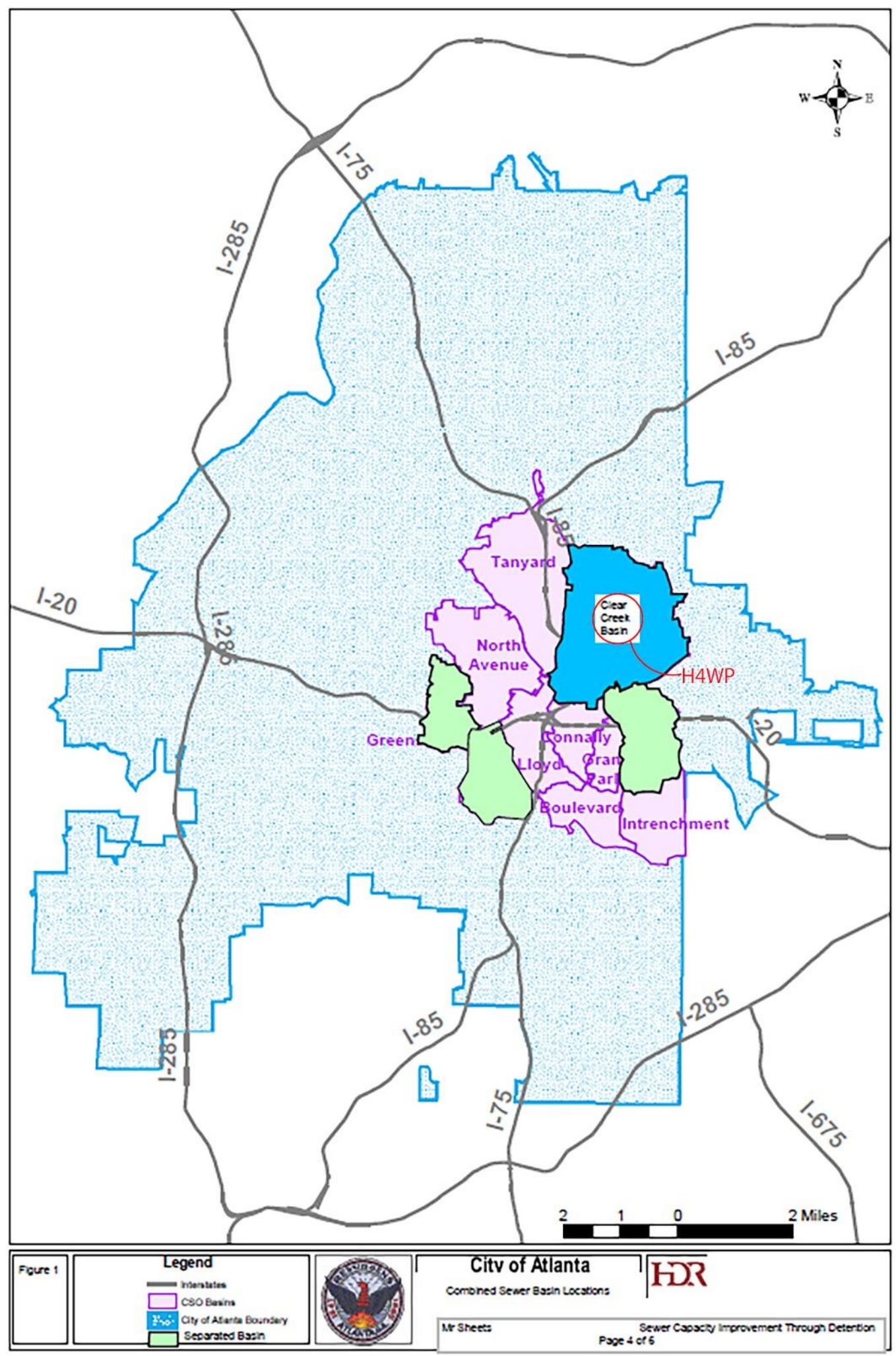

Figure 1. Clear Creek Combined Sewer Basin

Source: City of Atlanta Department of Watershed Management and HDR. 


\section{Clear Creek Basin.}

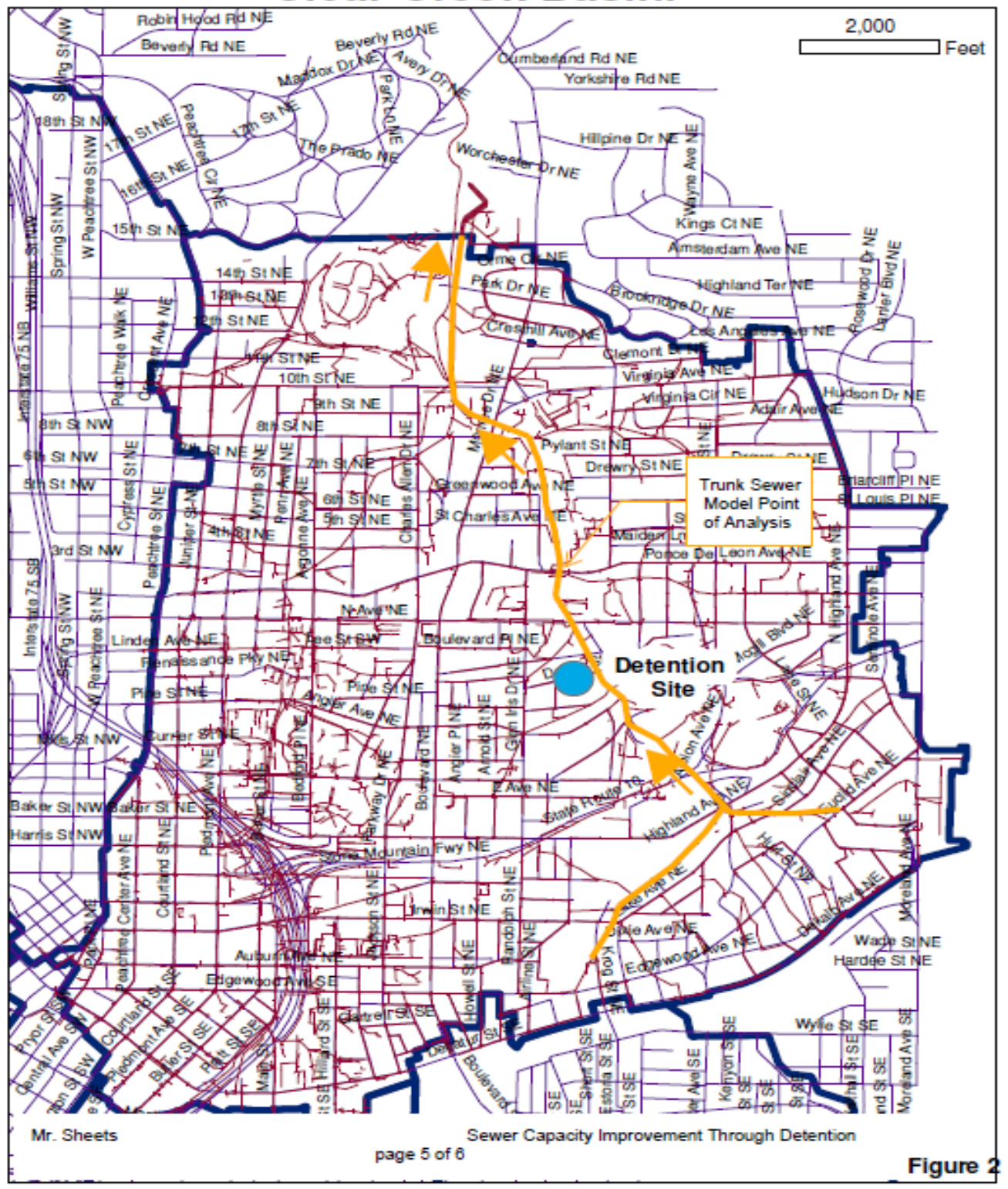

Figure 2. Clear Creek Sewer System

Source: City of Atlanta Department of Watershed Management and HDR.

\section{Calculations:}

A $9 \%$ improvement in the peak flow rate is equal to 44 millions of gallons per day reduction in the trunk sewer flows.

\section{Sources:}

City of Atlanta Department of Watershed Management and HDR. Clear Creek Combined Sewer Relief.

City of Atlanta Department of Watershed Management and HDR. Sewer Capacity Improvement Through Detention 


\section{Limitations:}

Modeled results are from InfoWorks and not an observed site measurement.

- Provides flood protection in extreme rain events for adjacent properties. There was no flooding at neighboring Ponce City Market during 3 days of intense rain in July 2013 totaling 5.3 in, as compared to catastrophic flooding of the market during 3 days of intense rain in September 2009 totaling 8.1 in.

\section{Methods:}

Prior to the construction of Historic Fourth Ward Park, the old Sears, Roebuck \& Co. building (now Ponce City Market) frequently flooded. Ponce City Market is across the street from the park and is one of the largest visitor destinations in the area (Figure 3). The Atlanta flood of September 2009 was particularly serious - over $\$ 500$ million in damage occurred, and ten people lost their lives ("Catastrophic Atlanta Flood of 2009"). The floods were the result of continuous prolonged rainfall from September 15-22, 2009. The rain fell faster than stormwater management systems could handle (“Catastrophic Atlanta Flood of 2009").

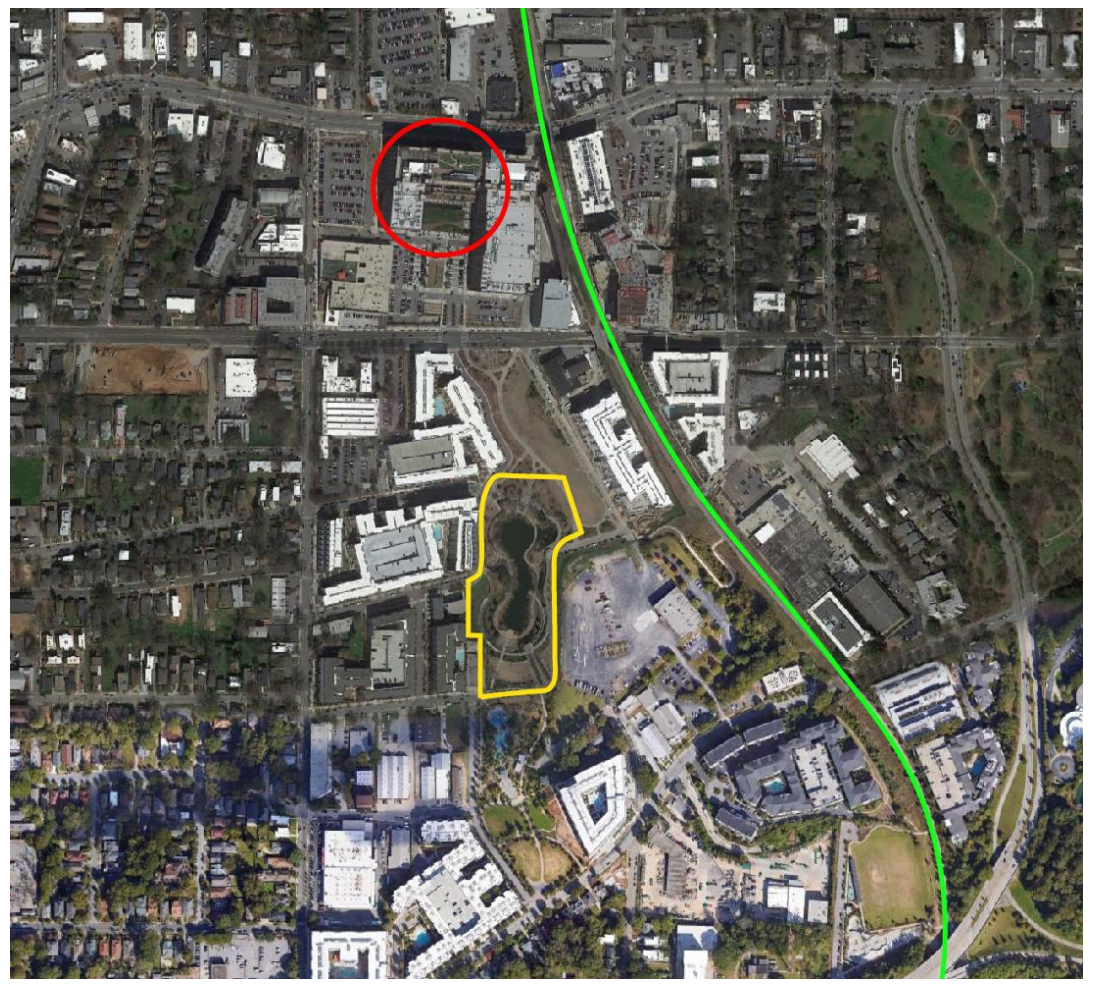

Figure 3. Ponce City Market (red circle), Atlanta BeltLine (green path), and Historic Fourth Ward Park (yellow outline). Adapted from Google Earth V 7.3.1.4507. Fulton County, GA, USA. $33.7694^{\circ} \mathrm{N}, 84.3648^{\circ} \mathrm{W}$. Google Imagery 2018, TerraMetrics, 2018. (Accessed July 11, 2018). 


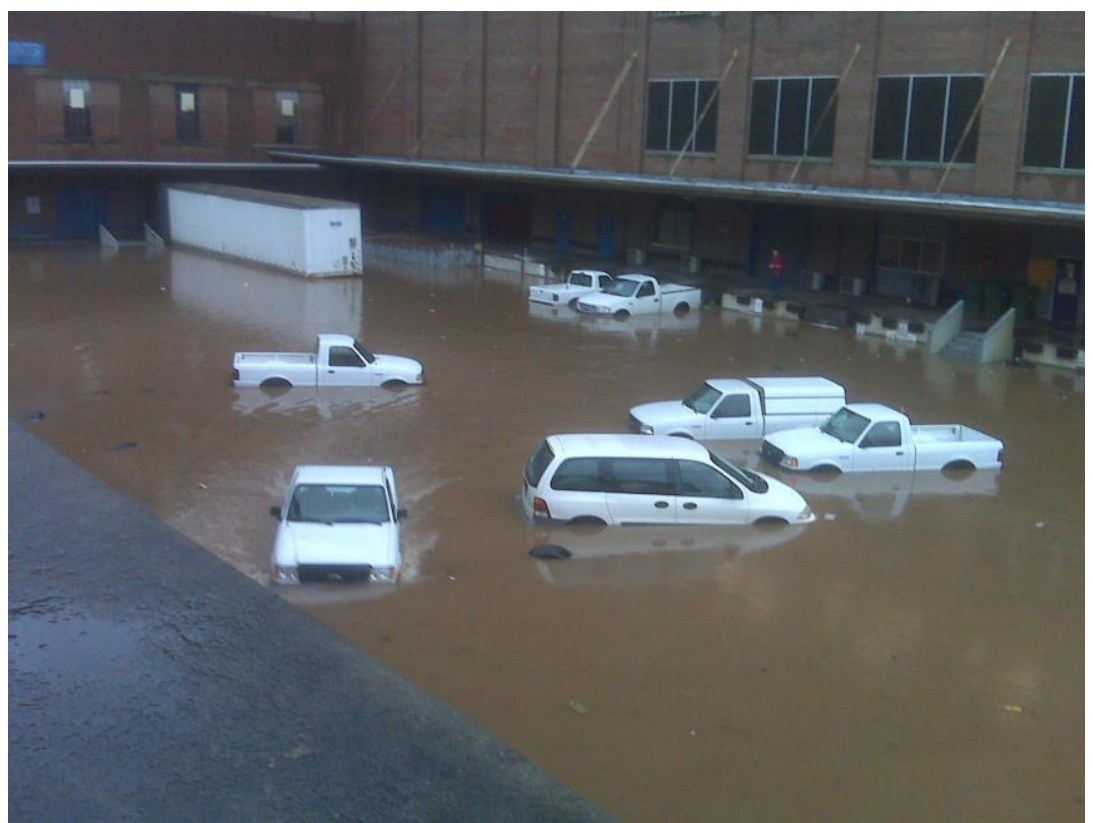

Figure 4. Flooding at the old Sears Roebuck Building (September 2009). Source: Kevin Burke of Atlanta BeltLine Inc.

Historic Fourth Ward Park is located in a low-lying portion of a 350-acre urban watershed that was susceptible to overflows during a storm as small as a 5-year event. No developer was willing to take the risks involved with buildings that frequently flood until measures such as the Historic Fourth Ward Park were put in place to manage the area's combined sewer overflow. A traditional engineering response would be a cut-and-cover installation of a new relief sewer and tunnel. However, dense development combined with the historic nature of many buildings made land acquisition difficult. Instead, Atlanta combined the need for more public green space and stormwater management and solved them both with a single project. 

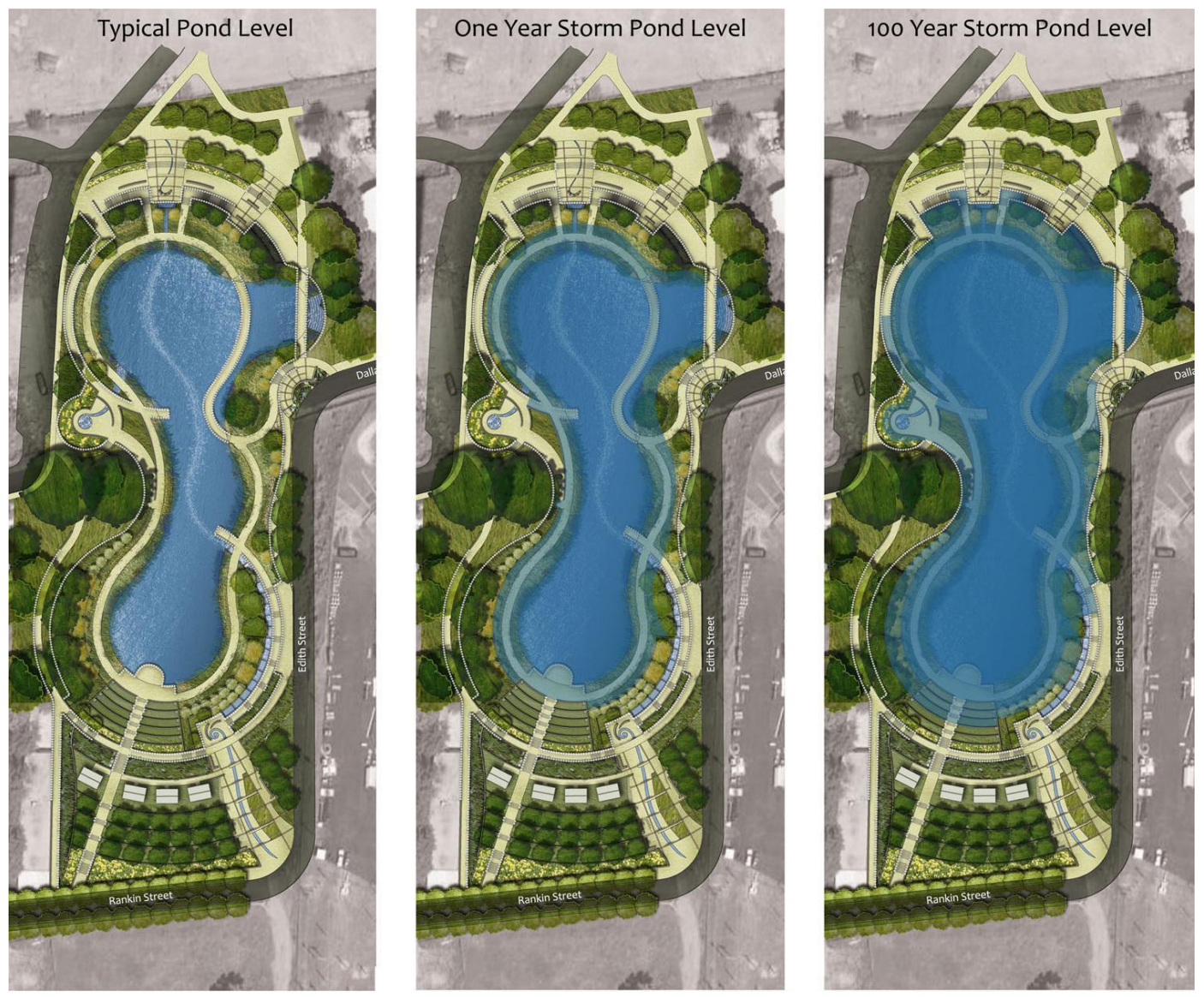

Figure 5. Typical ponding level, one year storm pond level, and 100-year storm pond level. Source: HDR.

\section{Calculations:}

Figure 4 shows flooding in September of 2009. During this time the highest daily rainfall was 4.99 inches with a 3-day total of 8.09 inches between September 19 and 21, 2009, resulting in a severely flooded Ponce City Market (Weather Underground). Between the days of July 19 and $21,2013,5.28$ inches of rain fell with a daily high of 2.43 inches (Weather Underground). This has been the highest three day total since the park's construction. Ponce City Market did not flood, providing proof of the park's ability to protect neighboring properties from flooding. Figure 3 shows the ponding levels in the park for various design storms.

\section{Sources:}

"Catastrophic Atlanta Flood of 2009." National Weather Service. Accessed July 2, 2018. https://www.weather.gov/ffc/atlanta floods anniv

Weather Underground. "Atlanta". Accessed July 2, 2018.

https://www.wunderground.com/weather/us/ga/atlanta

- Sequesters 6.3 tons of atmospheric carbon and intercepts approximately 19,200 gallons of stormwater runoff annually in 203 existing and newly-planted trees. 


\section{Methods:}

i-Tree Eco v6 is a software tool from the U.S. Forest Service that aims to provide forestry analysis and benefit assessment (i-Tree Eco v6). The software allows an accessible format for viewing the benefits of an individual tree. The research team entered the species and DBH (diameter at breast height) of the trees and the surrounding land-use into i-Tree. The DBH size and species on site were verified on June 17, 2018. Results illustrate carbon sequestration in pounds, carbon storage in pounds, and avoided runoff in cubic feet. Benefits are expected to increase as trees mature.

During storm events, a portion of the rain is intercepted by vegetation, transpired or infiltrated. Trees reduce the amount of surface runoff, which is the result of water not infiltrating the soil. Here, the percentage of trees with 6" caliper and under is $76.8 \%$ and the amount of avoided runoff provided by the trees is 19,090 gallons. This shows that newly-planted trees aid the basin in providing stormwater management benefits.

Carbon Capture and Storage is a crucial element in the process of tackling climate change. Carbon sequestration, which is the removal of carbon dioxide from the air, differs from carbon storage. Carbon storage is the amount of carbon reserved in the above and below ground portions of woody vegetation.

Studies show that an increase in tree cover leads to reduced ozone formation (Nowack and Dwyer 2000). Historic Fourth Ward Park has 35,770 sf of tree cover. The park also produces 1.468 tons of oxygen/year.

The most common trees on site are River Birch (13.8\%), Sweetbay (11.8\%), and Southern Wax Myrtle (18.7\%).

The one preserved pecan tree (Carya illinoinensis) accounts for $25.7 \%$ of the carbon storage and $7 \%$ of the annual carbon sequestration; emphasizing the value of preserving established trees. The older the tree is, the greater the resulting diameter and height of the tree, increasing the calculated amount of storage and sequestration exponentially.

\section{Calculations:}

i-Tree's database has values for different tree and size types. The calculation used to determine $\mathrm{CO}_{2}$ sequestered per tree $(\mathrm{kg})=$ tree mass $(\mathrm{kg}$ of fresh biomass) $\times 65 \%$ (dry mass) $\times 50 \%$ (carbon \%) x $3.67 \times 120 \%$. Avoided runoff is estimated based on local weather data from the nearest weather station. The total annual precipitation in 2015 was 72.4 inches.

$2,552 \mathrm{cu} \mathrm{ft}=19,090.29$ gallons

The amount of oxygen produced is estimated from carbon sequestration based on atomic weights: net $\mathrm{O}_{2}$ release $(\mathrm{kg} / \mathrm{yr})=$ net $\mathrm{C}$ sequestration $(\mathrm{kg} / \mathrm{yr}) \times 32 / 12(\mathrm{i}-$ Tree Eco v6). 


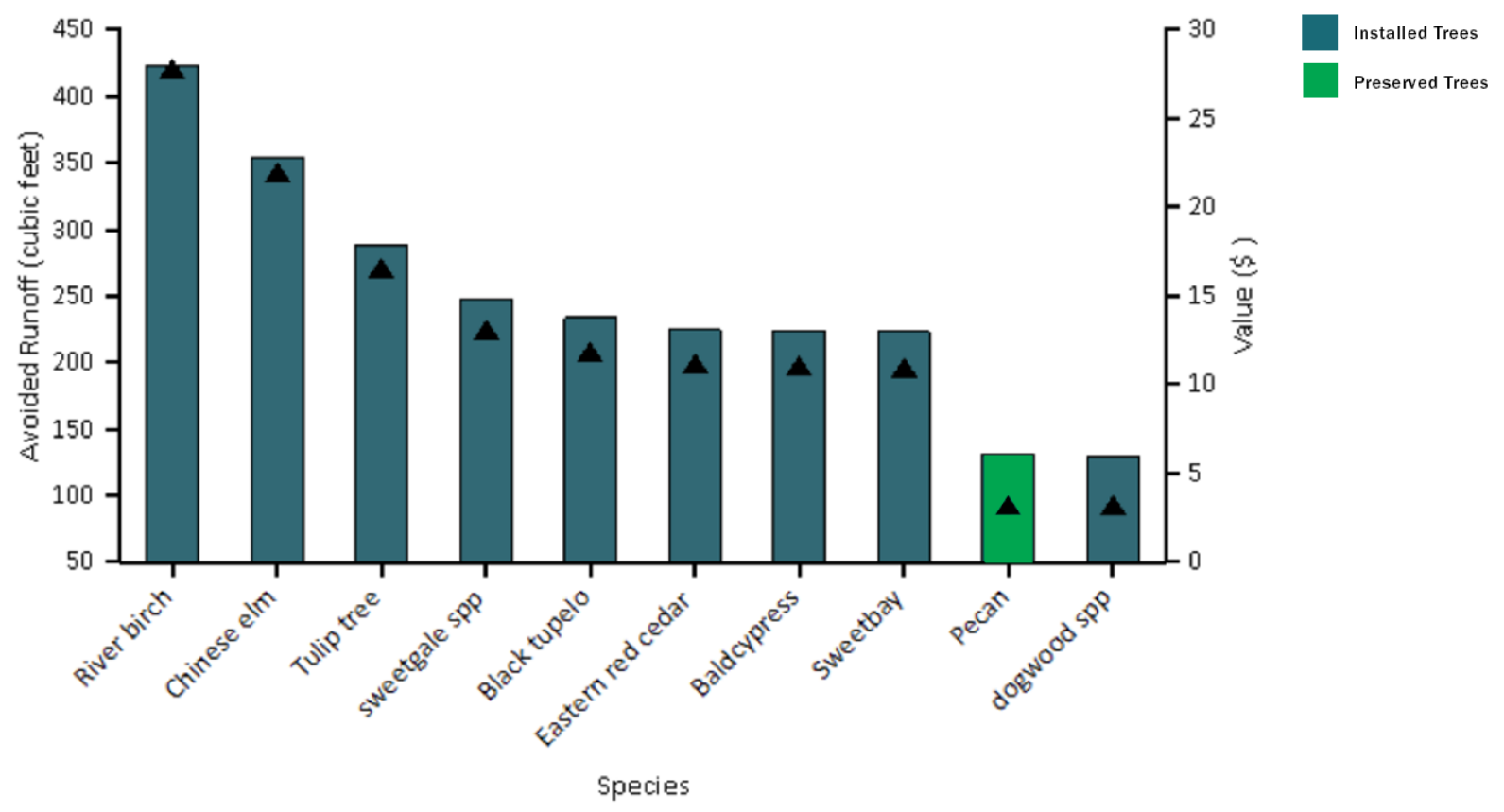

Figure 6. Avoided runoff (cf) by species ranked by greatest overall impact on runoff. Source: iTree Eco v6.

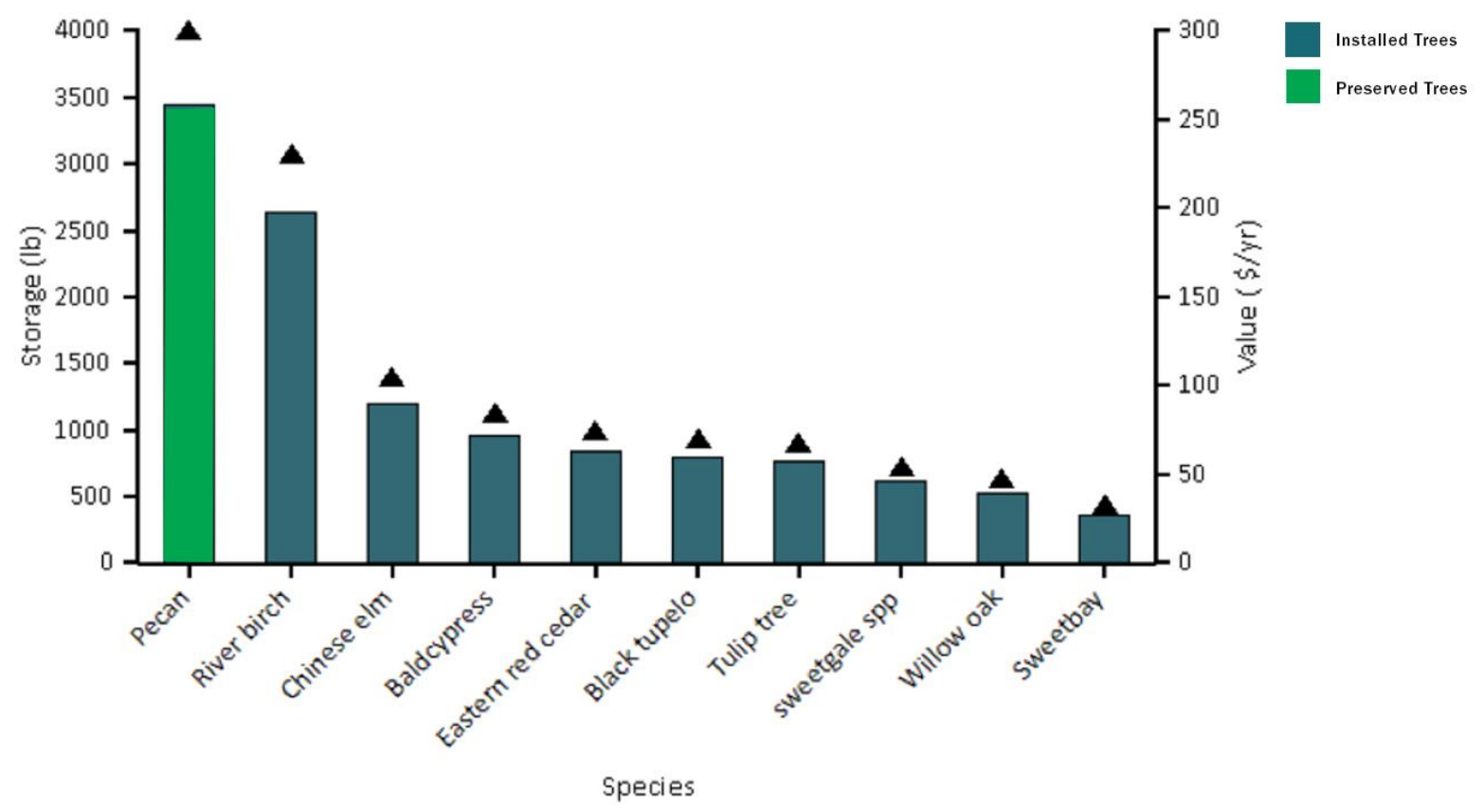

Figure 7. Carbon storage for trees with the greatest storage. Source: i-Tree Eco v6. 


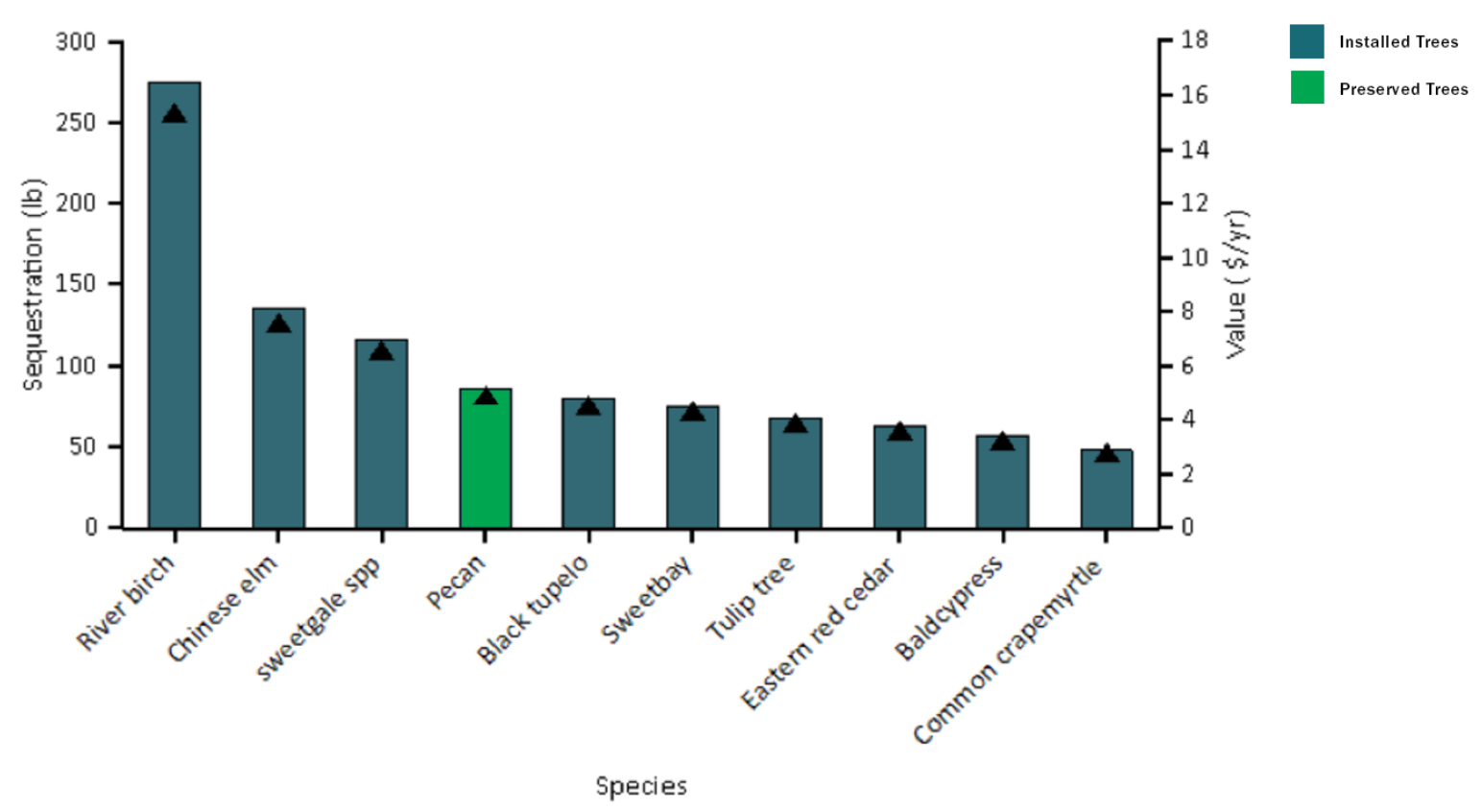

Figure 8. Annual carbon sequestration for tree species with the greatest sequestration. Source: i-Tree Eco v6.

\section{Sources:}

i-Tree Eco v6. Accessed July 2, 2018. https://www.itreetools.org/eco/index.php

Nowak, D.J.; Dwyer, J.F. 2000. Understanding the benefits and costs of urban forest ecosystems. In: Kuser, John, ed. Handbook of urban and community forestry in the northeast. New York, NY: Kluwer Academics/Plenum: 11-22.

\section{Limitations:}

The i-Tree results do not take into account any of the shrubs or groundcovers on the site. Benefits will increase over time.

\section{Social Benefits}

\section{Overall Methods:}

An intercept survey was developed, guided by precedents from Olin Partnership, to assess behavior and enjoyment of users (Olin Partnership, Email to Research Fellow, April 5, 2018). The survey was administered in June on a Wednesday, Sunday, and Monday from 9am to $5 \mathrm{pm}$. The researcher stood at high circulation points and asked each visitor when walking by if they would be interested in taking a survey. Respondents completed a digital survey on an iPad to assess their perceptions of the site based on 34 questions shown in the Appendix, which also included demographic questions. Results from respondents $(N=72)$ were summarized (Qualtrics and JMP 13.2.1). 
Overall Calculations:

Example Calculation (for all listed survey results):

Question: How often do you come here each week?

19 respondents answered daily

18 respondents answered $2-4$ times

72 total respondents

- $51 \%$ of respondents $(\mathrm{N}=72)$ visit the park more than twice per week.

$(19+18) / 72=.51 \times 100=51 \%$

Overall Sources:

Survey Questions (see appendix A)

Weather Underground - Atlanta. Accessed July 2, 2018.

https://www.wunderground.com/weather/us/ga/atlanta

\section{Overall Limitations:}

The sample size was limited due to the number of hours the research team could spend in the field. The researchers were aware of bias that can occur with convenience sampling. With the desire of obtaining a large sample size, researchers asked as many users as was feasible and had three iPads on site to allow for several users to take the survey at one time. Additional respondents would improve the reliability of the statistical results. Site visits occurred between 9am-5pm and were convenient for ease of administration; however, evening and early morning hours are busier times for the park compared to midday when the park is hottest. Also, to gather more participants surveying when an event was taking place would likely increase the number of responses.

- Serves the local community. $44 \%$ of 71 surveyed users live in a zip code within a 15-minute walking distance, and $88 \%$ of the 31 surveyed local users visit the park more than twice per week. Users are most attracted to the site because of its location, visual beauty, and water features.

Notable results of the survey regarding ways in which the landscape contributes to this benefit are as follows:

- $51 \%$ of respondents $(\mathrm{N}=71)$ visit the park 2 or more times per week.

- $62.5 \%$ of respondents $(\mathrm{N}=71)$ visit the park with 1 or 2 others.

- $65 \%$ of respondents $(\mathrm{N}=71)$ spend 30 minutes or more at the park.

- The mean age of survey respondents was 36 years old $(\mathrm{N}=71)$.

- $29 \%$ of respondents $(\mathrm{N}=71)$ were visiting from 30308 , Historic Fourth Ward Park's zip code.

- $44 \%$ of respondents ( $N=71$ ) were visiting from $30308,30306,30312$, or 30307 , the three zip codes within a 15-minute walk of the park. 
- $87.5 \%$ of respondents from a zip code within a 15 -minute walking distance $(\mathrm{N}=31)$ visit the park more than 2 times per week.

- $62 \%$ of respondents ( $\mathrm{N}=71)$ were visiting from Atlanta zip codes.

- $3 \%$ of respondents $(\mathrm{N}=71)$ were visiting from out of the country.

- $97 \%$ of respondents $(\mathrm{N}=71)$ were visiting from within in the United States.

- $9 \%$ of respondents ( $\mathrm{N}=71$ ) were visiting from another state besides Georgia.

- $88 \%$ of respondents $(\mathrm{N}=71)$ were visiting from within the state of Georgia.

A total of 244 descriptive terms were used by respondents to answer the question "what attracts you to this place?" Figure 9 shows the number of unique terms used as 48 . The Recodes portion shows the words that were modified by the researchers to combine like words or words that belong together. The Stemming portion shows words that had combined totals because they had the same root word. A dot appears after those words in Figure 10. Figure 10 shows respondents $(\mathrm{N}=72)$ listed water, location, and beauty as the primary reasons they are visiting the site. In addition, it lists all of the other factors of attraction to the site.

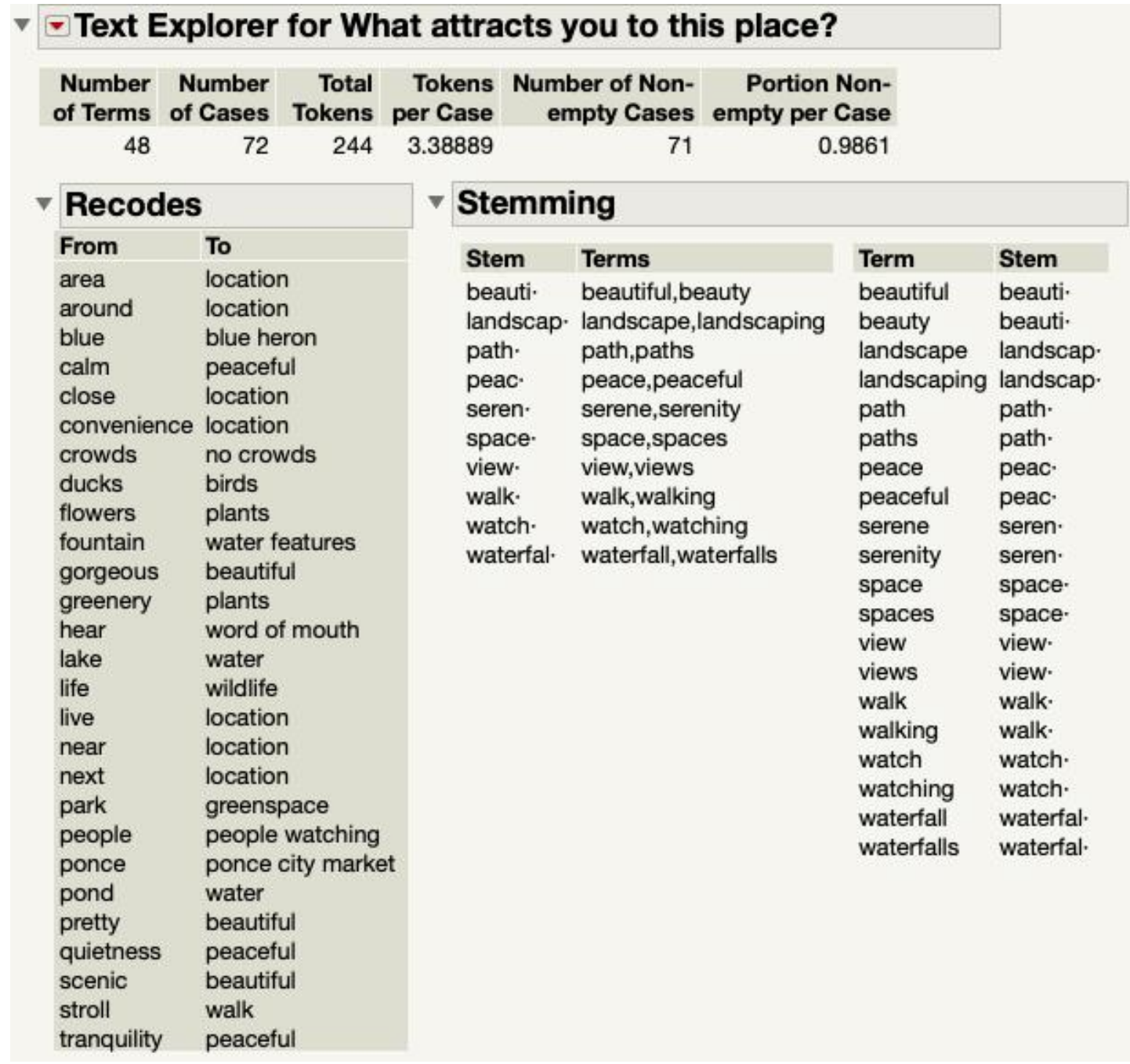

Figure 9. Recodes and stemming of responses to "what attracts you to this place?" Source: JMP. 


\section{Term and Phrase Lists}

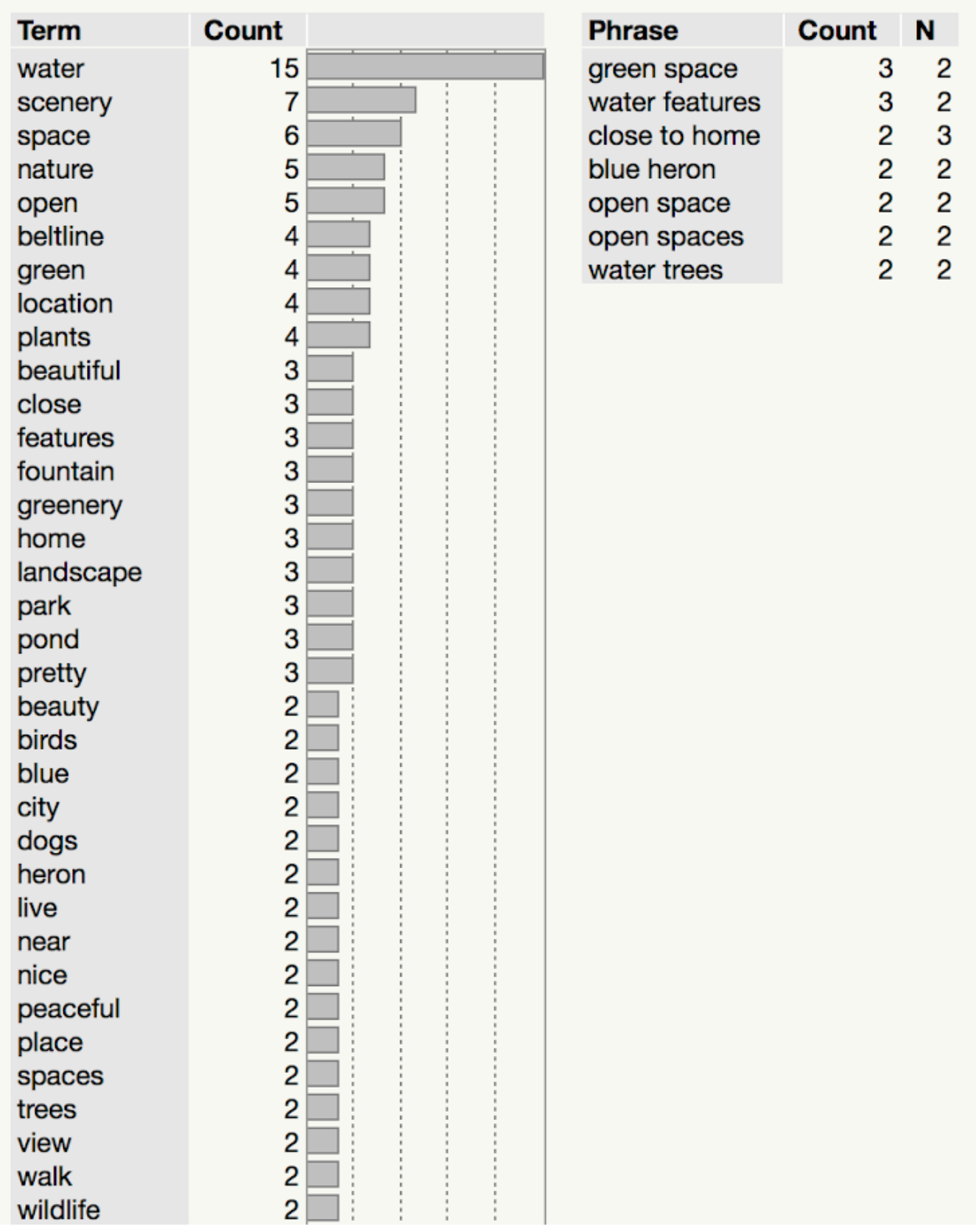

Figure 10. Term and phase lists showing frequency of responses to "what attracts you to this place?" Source: JMP.

Additional information: The survey also investigated what types of activities users do in the park. Figure 11 shows the number of unique terms used as 43 . The Recodes portion shows the words that were modified by the researchers to combine like words or words that belong together. The Stemming portion shows words that had combined totals because they had the same root word. A dot appears after those words in Figure 12. Figure 12 shows respondents $(\mathrm{N}=72)$ listed walking, walking their $\operatorname{dog}(\mathrm{s})$, and relaxing as the primary reasons they are visiting 
the site. In addition, it lists all of the other activities the respondents were doing in the park. A total of 214 descriptive terms were used by respondents to answer "what types of things do you do in this place?"

\section{Text Explorer for What types of things do you do in this place?}

\begin{tabular}{|r|r|r|r|r|r|}
$\begin{array}{r}\text { Number } \\
\text { of Terms }\end{array}$ & $\begin{array}{r}\text { Number } \\
\text { of Cases }\end{array}$ & $\begin{array}{r}\text { Total } \\
\text { Tokens }\end{array}$ & $\begin{array}{r}\text { Tokens } \\
\text { per Case }\end{array}$ & $\begin{array}{r}\text { Number of Non- } \\
\text { empty Cases }\end{array}$ & $\begin{array}{r}\text { Portion Non- } \\
\text { empty per Case }\end{array}$ \\
\hline 43 & 72 & 214 & 2.97222 & 70 & 0.9722
\end{tabular}

\begin{tabular}{|ll|}
\hline Recodes & \\
\hline From & To \\
appreciate & admire \\
conversations & talk \\
falls & waterfalls \\
hang & hangout \\
people & people watch \\
photos & take photos \\
pictures & take photos \\
piedmont & piedmont park \\
pond & water \\
socialize & talk \\
stroll & walk
\end{tabular}

\section{$\checkmark$ Stemming}

$\begin{array}{ll}\text { Stem } & \text { Terms } \\ \text { admir. } & \text { admire,admiring } \\ \text { dog. } & \text { dog,dogs }\end{array}$

Term Stem

admire admir. admiring admir.

dog dog.

dogs dog.

Figure 11. Recodes and stemming of responses to "what types of things do you do in this place?" Source: JMP. 


\section{v Term and Phrase Lists}

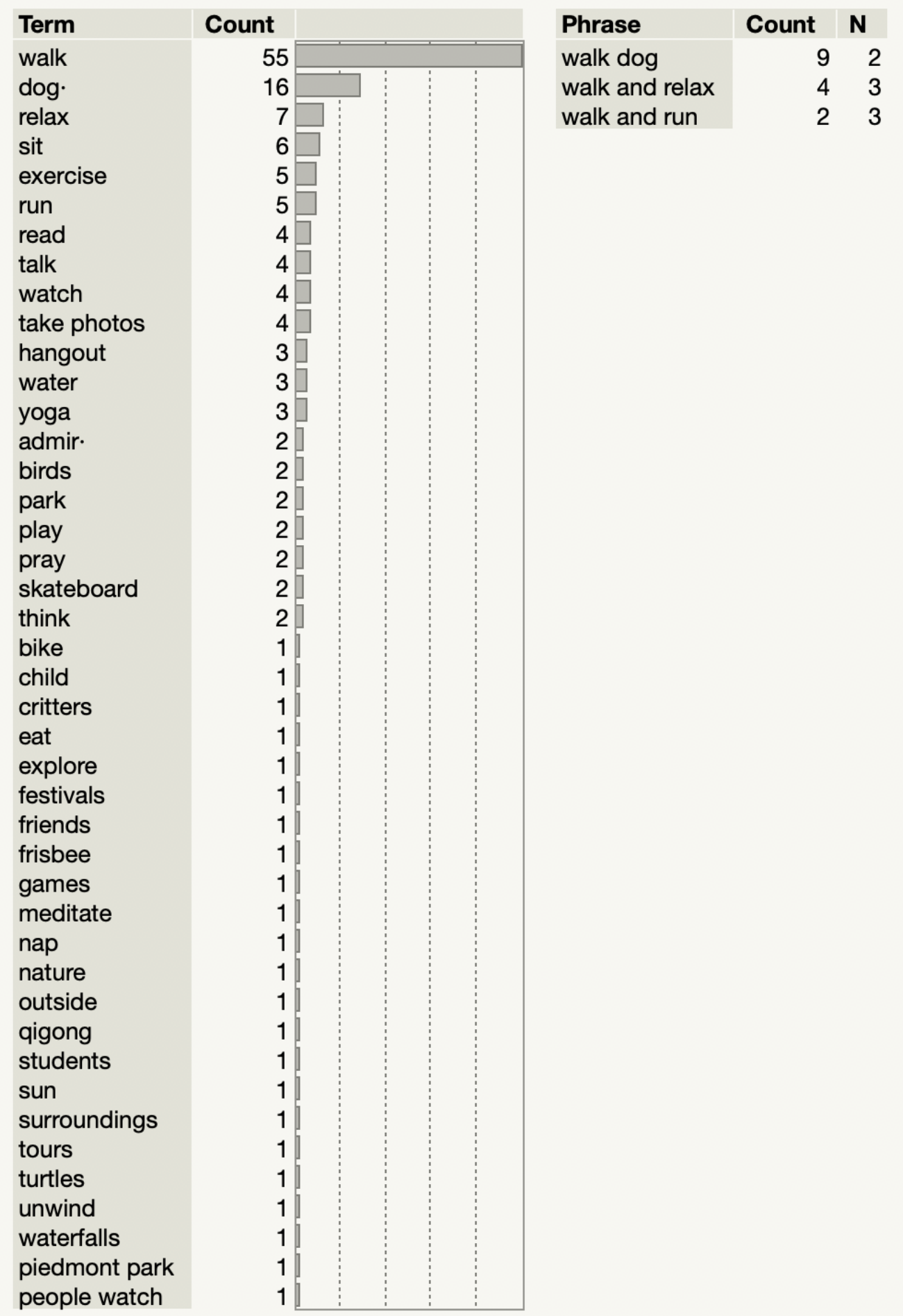

Figure 12.Term and phase lists showing frequency of responses to "what types of things do you do in this place?" Source: JMP. 


\section{Limitations:}

Recoding text in JMP requires some interpretation of individual responses. Further grouping of terms can be done, but researchers chose to do minimal grouping to display more unique descriptors.

- Provides a sense of escape and relief from being indoors according to $96 \%$ of 72 survey respondents.

Notable results of the survey regarding ways in which the landscape contributes to this benefit are as follows:

- $96 \%$ of respondents $(\mathrm{N}=72)$ agree this place provides a sense of escape and relief from being indoors

- The percentage of participants that felt a real sense of escape and relief from being outdoors did not differ by age, $\mathrm{c}^{2}(4, \mathrm{~N}=70)=2.56, \mathrm{p}=.63$.

- $90 \%$ of respondents $(\mathrm{N}=72)$ say this is a good place to hang out.

- $71 \%$ of respondents $(\mathrm{N}=72)$ agree this place encourages interaction with others.

- $80 \%$ of respondents $(\mathrm{N}=72)$ say this is a good place to read or study.

- $97 \%$ of respondents $(\mathrm{N}=72)$ say this area includes abundant healthy green plants.

- $97 \%$ of respondents $(\mathrm{N}=72)$ say there is a diverse mix of trees, vines, flowers, and shrubs that attract wildlife.

- $100 \%$ of respondents $(\mathrm{N}=71)$ say there are pleasant views with interesting things to see.

- $94 \%$ of respondents $(\mathrm{N}=70)$ say the area is overall fairly quiet, and free from obnoxious noises.

- $78 \%$ of respondents $(\mathrm{N}=72)$ say there are at least one or more choices of private outdoor places to sit.

- $83 \%$ of respondents $(\mathrm{N}=72)$ say there are comfortable places to linger or greet people.

When surveying park visitors, several expressed that Historic Fourth Ward Park feels like an oasis in the middle of a bustling city. The park seems to offer a unique escape to many people whether they work or live in the area.

- Creates a feeling of safety for $92 \%$ of 72 surveyed users. $84 \%$ of 33 surveyed female users reported feeling safe in the park.

Notable results of the survey regarding ways in which the landscape contributes to the academic value of the site are as follows:

- $92 \%$ of respondents $(\mathrm{N}=70)$ say they feel safe in the park.

- $84.85 \%$ of the female respondents $(\mathrm{N}=33)$ felt safe in the park.

- $97.37 \%$ of male respondents $(\mathrm{N}=38)$ felt safe in the park.

- The percentage of participants that felt safe in the park differ by more than $10 \%$ by gender, $c^{2}(1, N=70)=6.753, p=.0094$. 


\begin{tabular}{|l|l|l|l|}
\hline Gender & Strongly Agree & Agree & Neutral \\
\hline Female & $63.64 \%$ & $21.21 \%$ & $15.15 \%$ \\
\hline Male & $42.11 \%$ & $55.26 \%$ & $2.63 \%$ \\
\hline
\end{tabular}

Table 1. Male and female response percentages to "I feel safe in this place." Source: JMP.

It should be noted that when constructed was completed, Historic Fourth Ward Park had one of the largest displays of LED lighting in the state (Burke 2018). It can be inferred that this contributes to feelings of safety at night.

\section{Sources:}

Burke, Kevin. 2018. Interview with Rachael Shields. June 17.

\section{Economic Benefits}

\section{Overall Methods:}

The boundary for the analysis of the economic data includes the census tract (13121001700) that Historic Fourth Ward Park is located in. The tract is shown as 17 on the map below (Figure 12). Choosing a census tract as the boundary allowed for easy data analysis since much of the available data was organized by census tract.

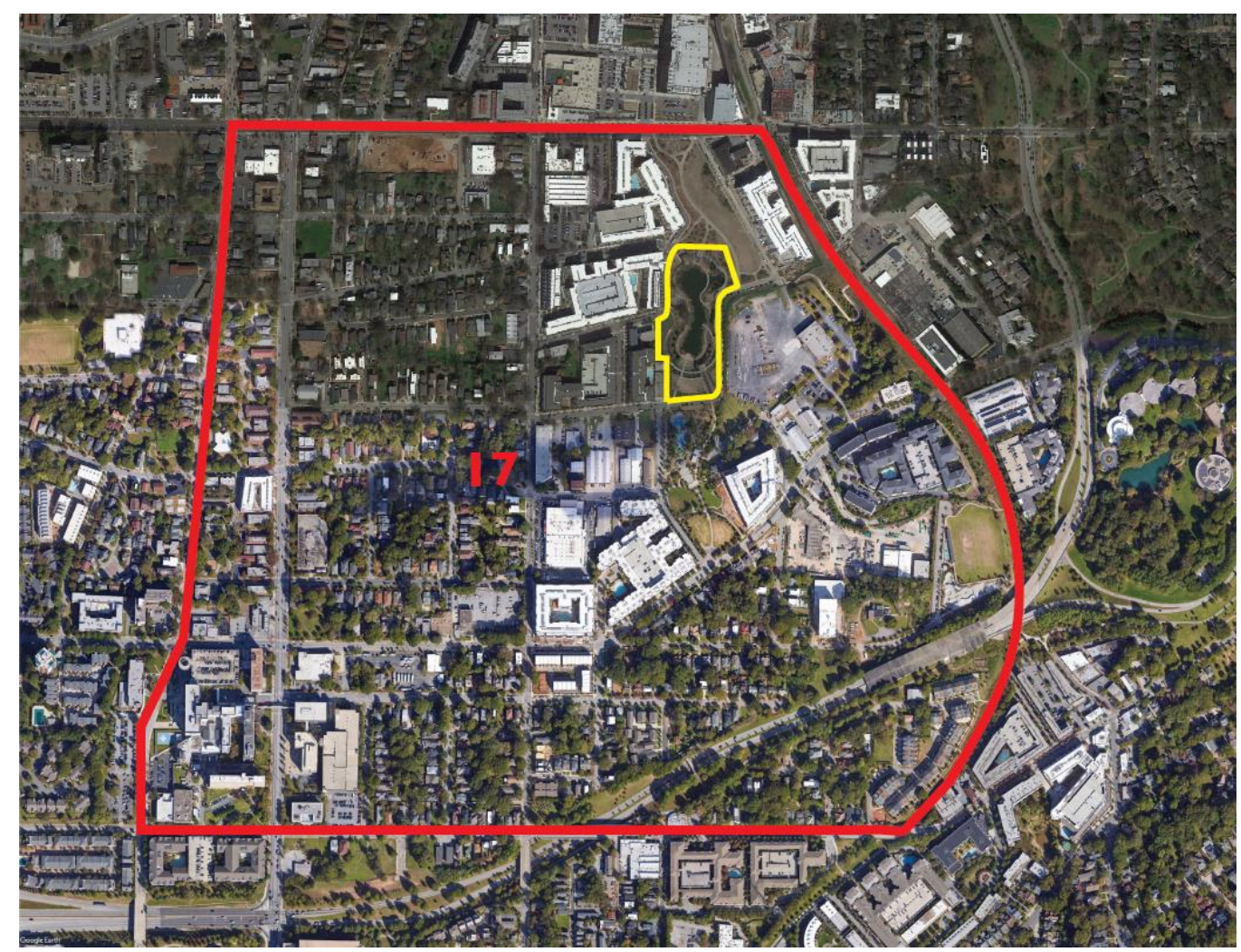


Figure 12. Census tract 17 (red outline) and Historic Fourth Ward Park (yellow outline). Adapted from Google Earth V 7.3.1.4507. Fulton County, GA, USA. 33.7694 N, 84.3648 W. Google Imagery 2018, TerraMetrics, 2018. (Accessed June 10, 2018).

The completion date of Historic Fourth Ward Park is 2010. All benefits are based on comparing the most recent data to data from before 2010 .

\section{Overall Sources:}

PolicyMap. Accessed December 31, 2018.

http://uga.policymap.com.proxy-remote.galib.uga.edu/maps

\section{Overall Limitations:}

A limitation of the economic portion of this study is difficulty in separating the park's impact from that of Ponce City Market, which is across the street from the park's north border, and the impact of the Atlanta BeltLine on the eastern border of the park's census tract. The census tract selected does not include Ponce City Market; however, the benefits of Historic Fourth Ward Park, Ponce City Market, and the Atlanta BeltLine blur together. In addition, construction occurred in the middle of the recession. Figures 14 and 15 use "workers earning $>\$ 40,000$ " as a proxy for economic well-being and thus show the economic diversity of the surrounding census tracts and the difficulty of separating out the effect of a park in that location, during this time period. Nevertheless, Figure 14 shows slow or no improvement in the district $(3.81 \%$ decline to $4.43 \%$ ) in $2010-11$, but very strong improvement (18.82\% or more) during $2014-15$. Because of the high variability locally and the rapidly changing economies of Atlanta neighborhoods during the 2008-18 time period, we believe that more reliable and useful comparisons of economic well-being are made between the Historic Fourth Ward Park tract and Fulton County. 


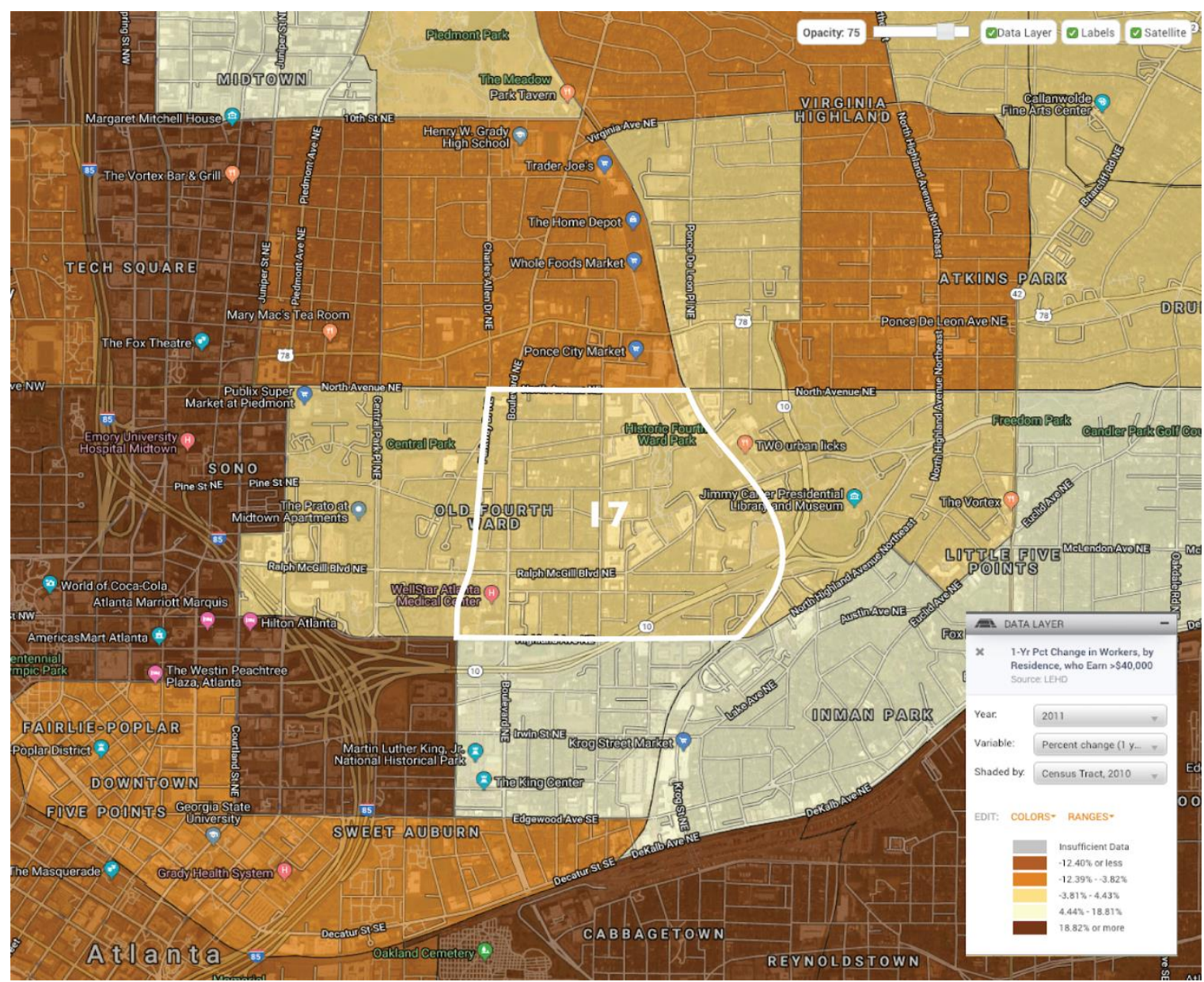

Figure 14. 2010-2011 1-Year Percent Change in Workers by Residence who Earn $>\$ 40,000$. Source: PolicyMap 


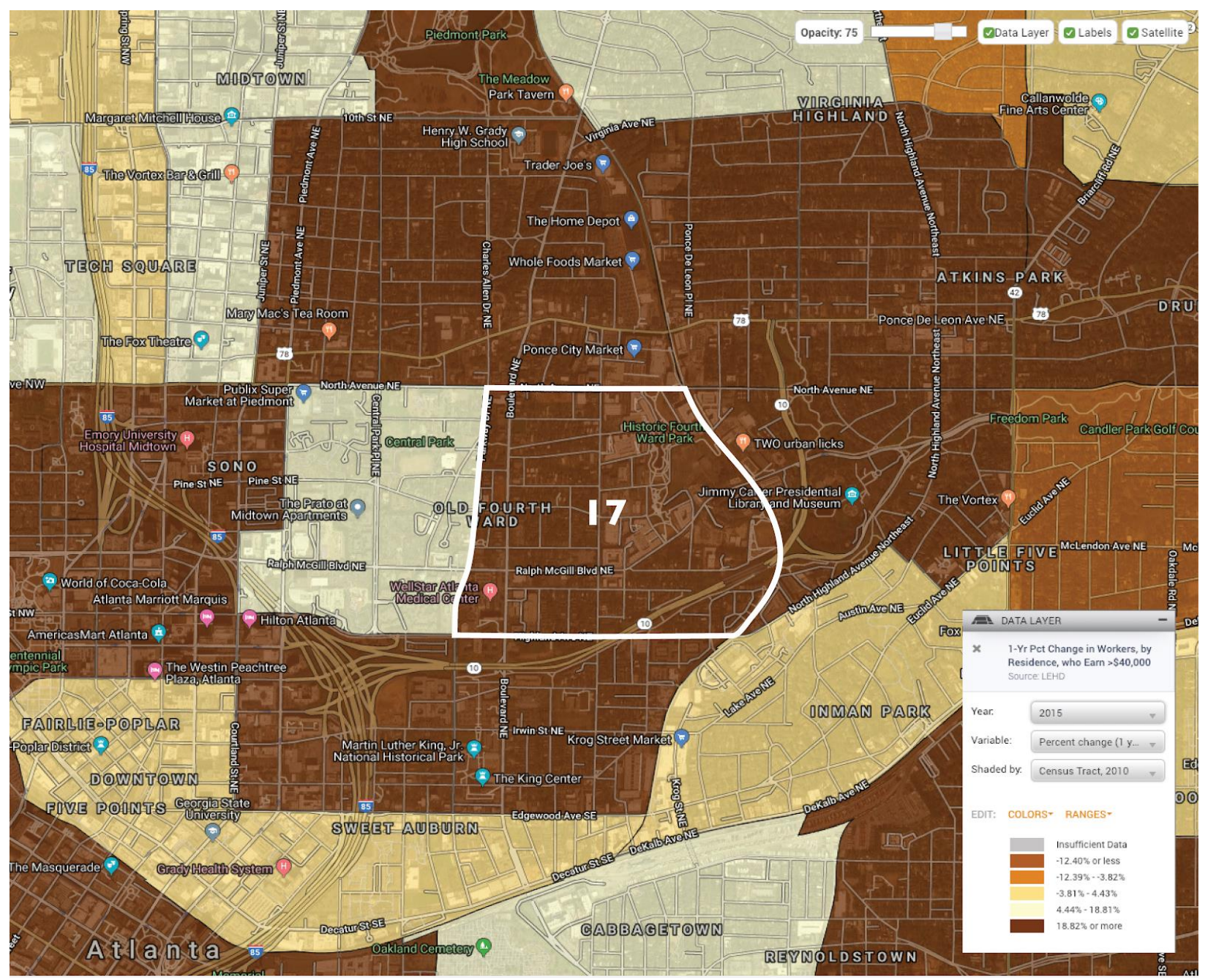

Figure 15. 2014-2015 1-Year Percent Change in Workers by Residence who Earn $>\$ 40,000$. Source: PolicyMap

- Contributed to a $118 \%$ increase in the percentage of homes gaining value in the Old Fourth Ward neighborhood from 42\% in 2007 to $91 \%$ in 2018, compared to an $82 \%$ increase in the percentage of homes gaining value in Atlanta as a whole.

\section{Methods:}

Zillow Research was used to access home value data before and after the construction of the park (Zillow Research). For comparison, the median percent of homes increasing in value for all Atlanta neighborhoods was included. Similar to the percent of homes increasing in value is Zillow's Home Value Index. Figure 16 shows Old Fourth Ward vs. Atlanta home values as well 7as a forecast for 2019, showing the increasing trend continues with Old Fourth Ward prices being higher than that of Atlanta's as a whole. The Zillow Home Value Index overcomes biases of median sale price indices and repeat sale indices that don't account for time period changes (Zillow Research 2014). 


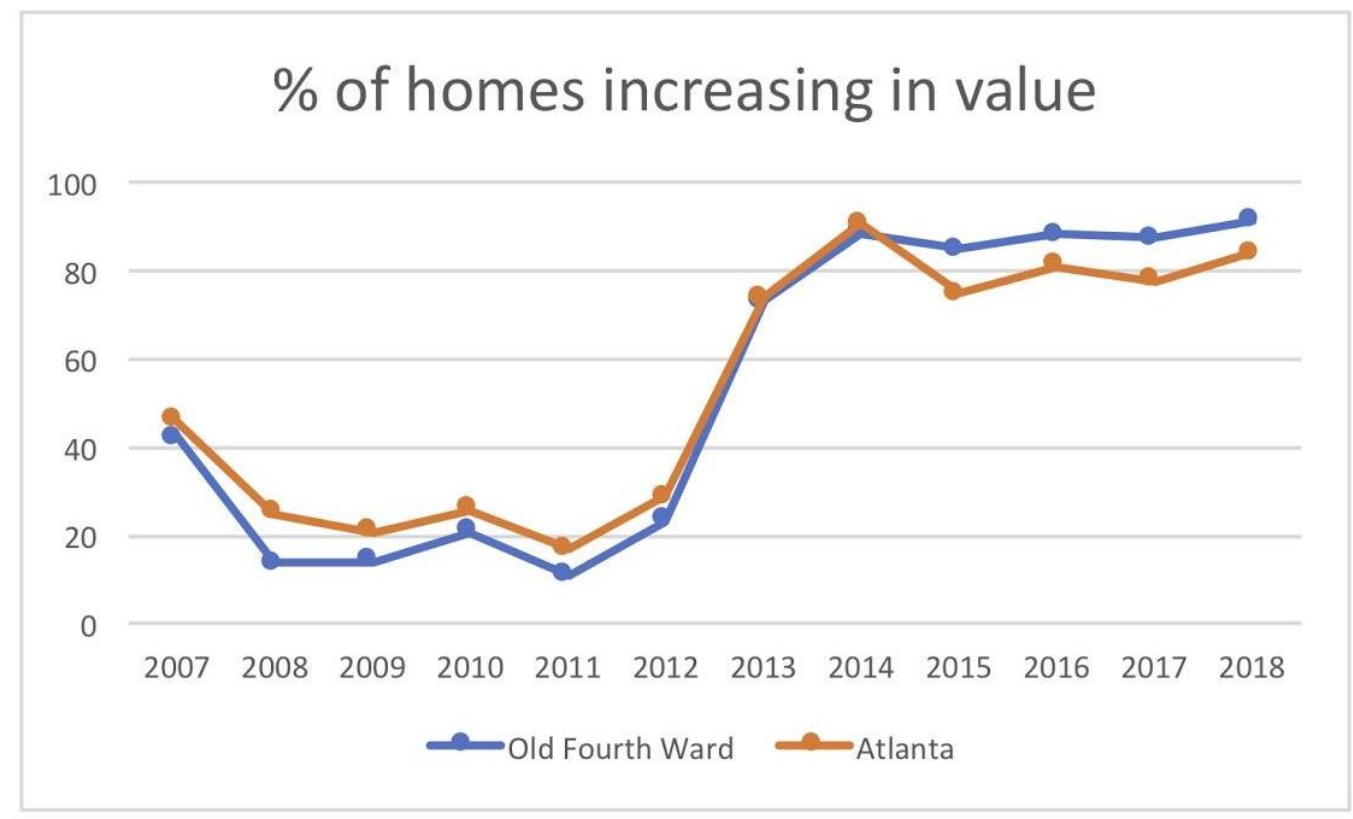

Figure 16. Percent of homes increasing in value. Source: Based on data from Zillow Research.

May 2019 — Old Fourth Ward \$277K — Atlanta $\$ 248 \mathrm{~K}$

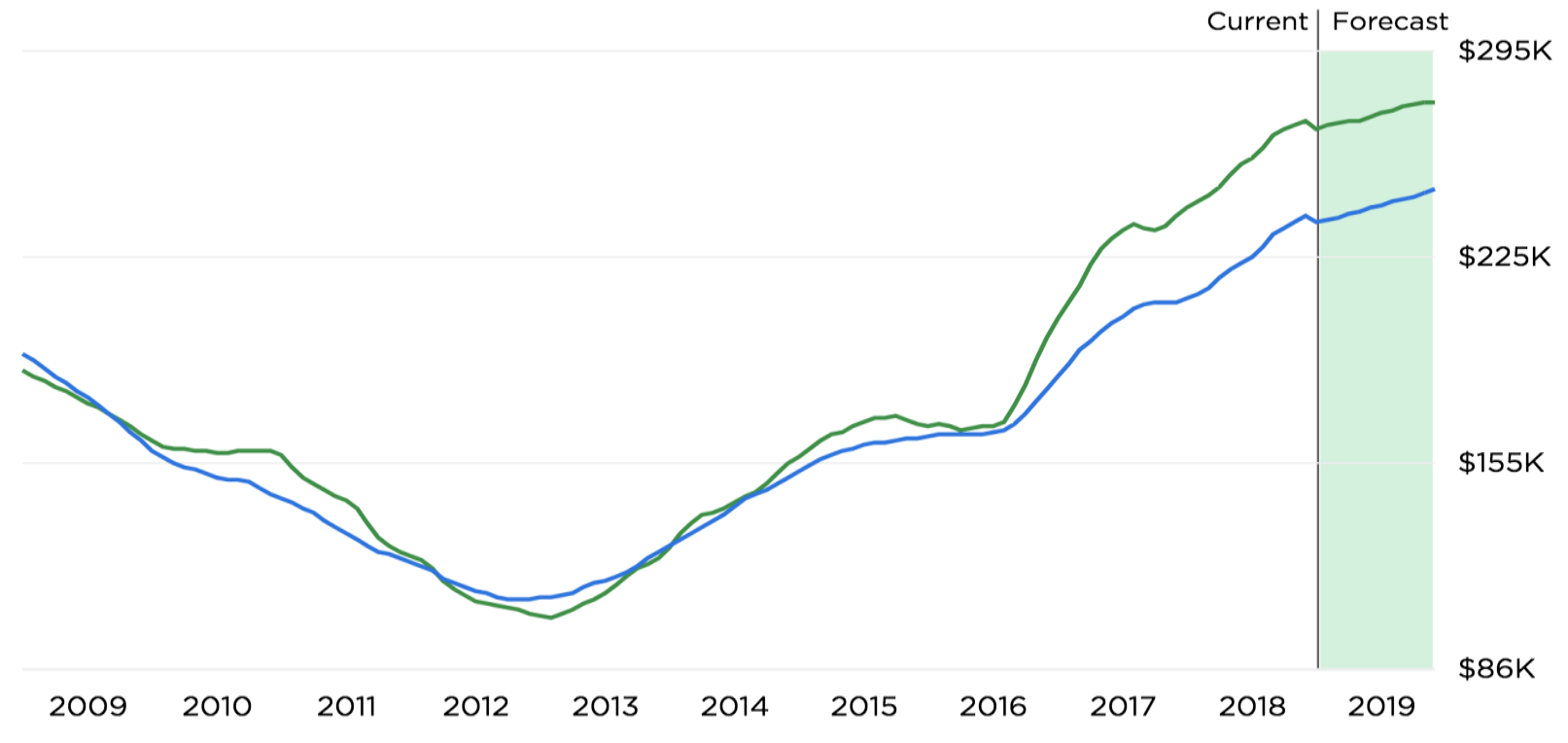

Figure 17. Zillow Home Value Index. Source: Zillow Research. 


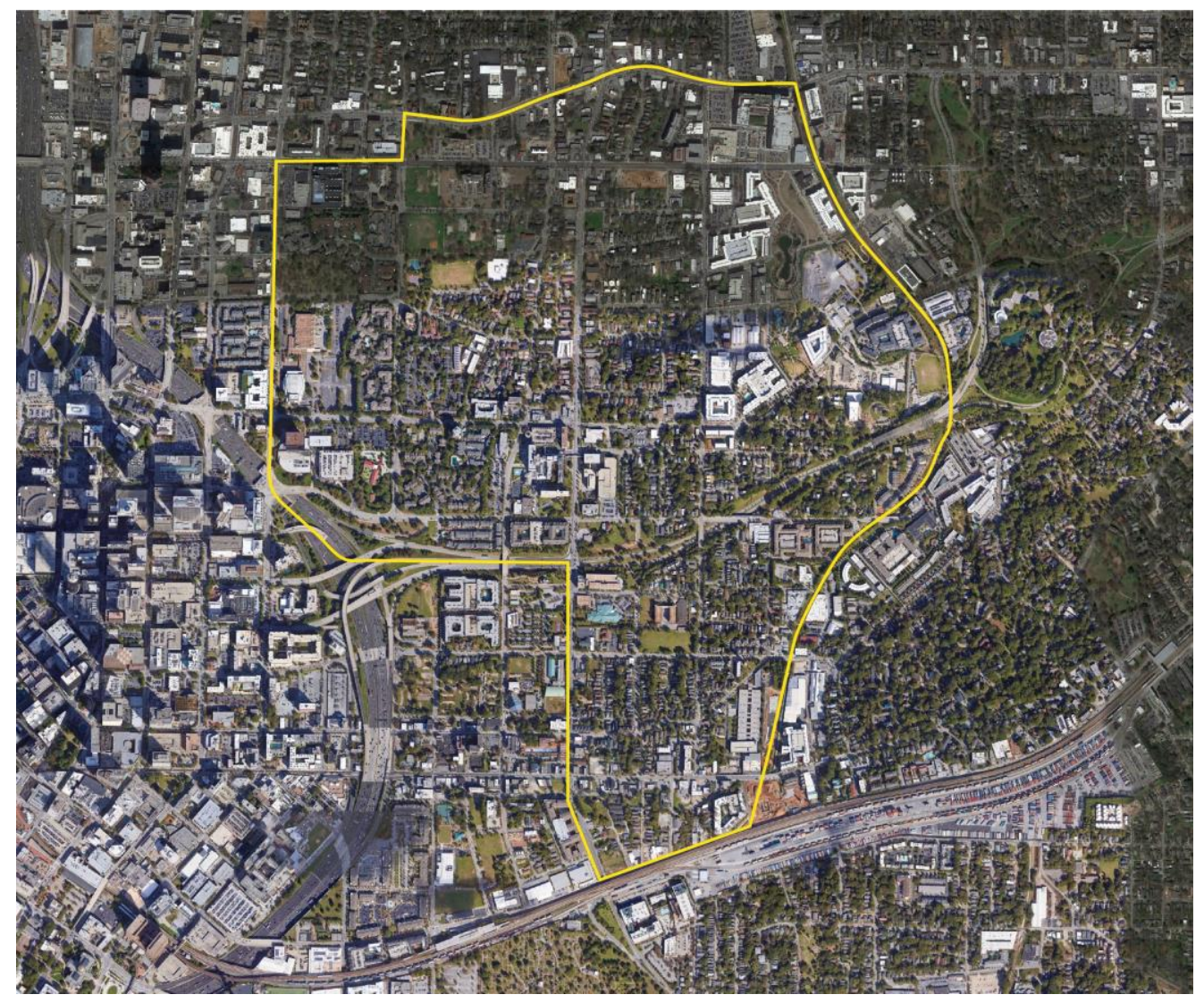

Figure 18. Old Fourth Ward neighborhood boundary. Adapted from Google Earth V 7.3.1.4507. Fulton County, GA, USA. 33.7694 N, 84.3648 W. Google Imagery 2018, TerraMetrics, 2018. (Accessed July 11, 2018).

\section{Calculations:}

Percent of Homes Increasing in Value in Old Fourth Ward Neighborhood:

Percent of Homes Increasing in Value (2007): 42.1\%

Percent of Homes Increasing in Value (2018): $91.19 \%$

Amount of Change: $+49.09 \%$

Percent Change: $+118 \%$

Percent Change Calculation: $((91.19-42.1) / 42.1)^{\star} 100$

Median Percent of Homes Increasing in Value in Atlanta Neighborhoods:

Median Percent of Homes Increasing in Value (2007): 47\%

Median Percent of Homes Increasing in Value (2018): 85.75\%

Amount of Change: $+38.65 \%$

Percent Change: $+82 \%$

Percent Change Calculation: $((87.75-47) / 47)^{\star} 100$

\section{Sources:}

Zillow Research. Accessed July 2, 2018. https://www.zillow.com/research/data/ 
Zillow Research. 2014. Accessed July 2, 2018. https://www.zillow.com/research/zhvimethodology-6032/

\section{Limitations:}

In this benefit the smallest boundary available for analysis was neighborhood-based. While the Historic Fourth Ward Park census tract doesn't include Ponce City Market, the neighborhood does.

- Contributed to a $56 \%$ increase in median property tax revenue in the surrounding census tract from 2009 to 2016, compared to a $0.27 \%$ decrease in median property tax revenue for Fulton County as a whole.

\section{Methods:}

The U.S. Census Bureau American Fact Finder was used to access census data before and after the construction of the park (United States Census Bureau). For comparison, the county median was included.

\section{Calculations:}

Property Taxes Census Tract 17:

Median Dollars (2009): \$2,384

Median Dollars (2016): $\$ 3,708$

Amount of Change: $+\$ 1,324$

Percent Change Calculation: $((\$ 3,708-\$ 2,384) / \$ 2,384)^{*} 100$

Percent Change: $+55.53 \%$

Property Taxes Fulton County:

Median Dollars (2009): \$2,988

Median Dollars (2016): \$2,980

Amount of Change: $-\$ 8$

Percent Change Calculation: $((\$ 2,980-\$ 2,988) / \$ 2,988) * 100$

Percent Change: $-0.27 \%$

\section{Sources:}

United States Census Bureau - American Fact Finder. Accessed July 2, 2018.

https://factfinder.census.gov

\section{Limitations:}

2016 was the most recent data available for median property tax revenue in the area. While 2009 was not the earliest available data, earlier data would more heavily have reflected the impact of the financial crisis of 2008. 
- Catalyzed more than $\$ 2$ billion worth of investment in the 6 blocks adjacent to the park, and developers are projected to spend more than an additional \$1 billion in the area in coming years.

\section{Methods:}

After speaking to five developers in Old Fourth Ward, it is clear that the park was the primary reason developers were first attracted to the area (Clark 2018; Irwin 2018; Munger 2018).

Jim Irwin, CEO of New City, is on the board for Historic Fourth Ward Park Conservancy and was a Senior Vice President at Jamestown when Ponce City Market was being constructed. New City is currently developing the former Georgia Power site (760 Ralph McGIII) and a new Kroger grocery store (725 Ponce) both adjacent to the park. Jamestown is the developer that renovated Chelsea Market in New York City and now also Ponce City Market located across the street from the park.

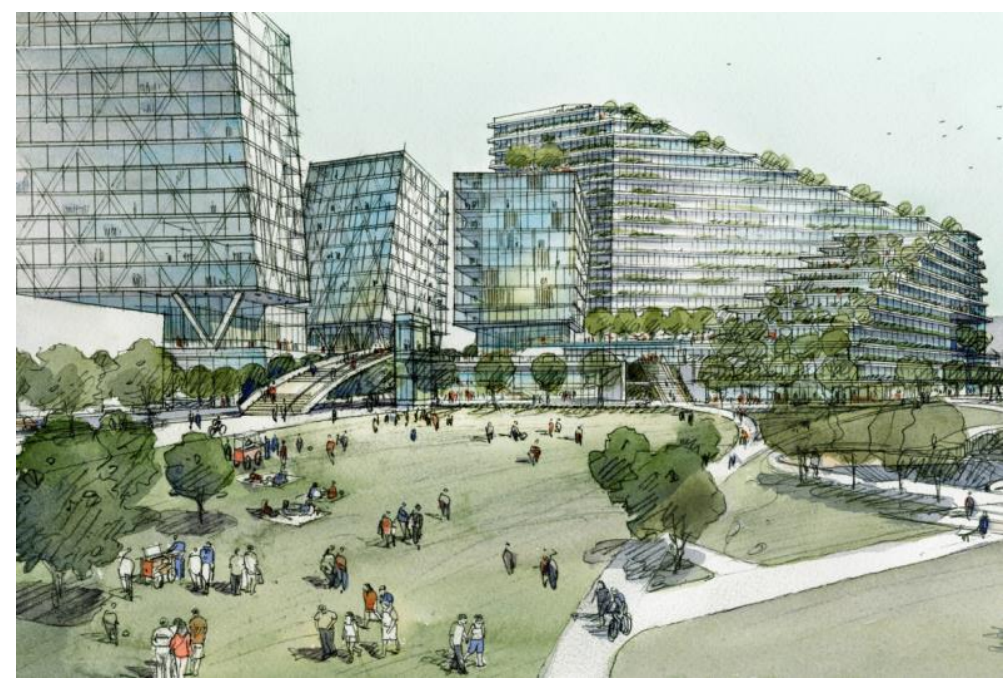

Figure 19. 760 Ralph McGill development. Source: New City Properties.

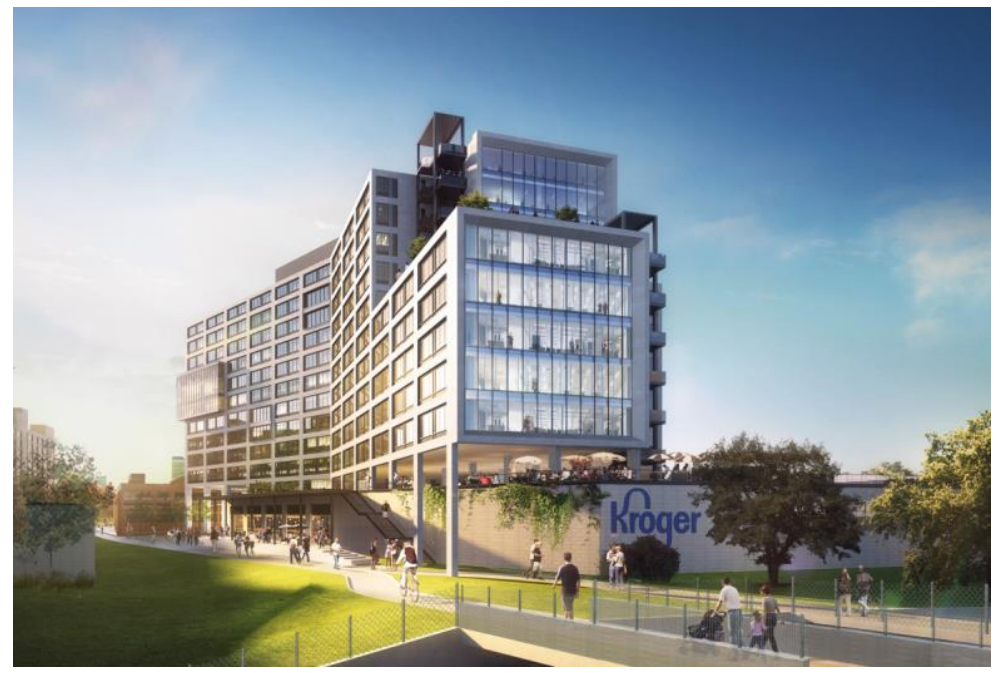

Figure 20. 725 Ponce development. Source: New City Properties. 
In an interview with Jim Irwin, he mentioned that Jamestown would not have purchased the Sears, Roebuck \& Co. building if it had not been for Historic Fourth Ward Park (Irwin 2018). They required a certificate stating that the park would prevent the building from flooding again. Before the park's construction, flooding would float manhole covers and flood the bottom floor of the Sears building. Richard Munger is a Sr. Vice President at North American Properties and a board member of Historic Fourth Ward Park Conservancy. Munger said that NAP required the park to be finished before developing in the area, and now all the developers are putting in maximum effort to get properties near the park (Munger 2018). Jay Clark is the CEO and founder of Southeast Capital Companies and a board member of the Historic Fourth Ward Park Conservancy. Clark mentioned the park was a primary reason for building in the area, and had not known of plans for Ponce City Market or the BeltLine (Clark 2018). All of the developers mentioned that Old Fourth Ward is currently listed as the hottest submarket in Atlanta, and we can infer the park had a large role in that (Clark 2018; Irwin 2018; Munger 2018).
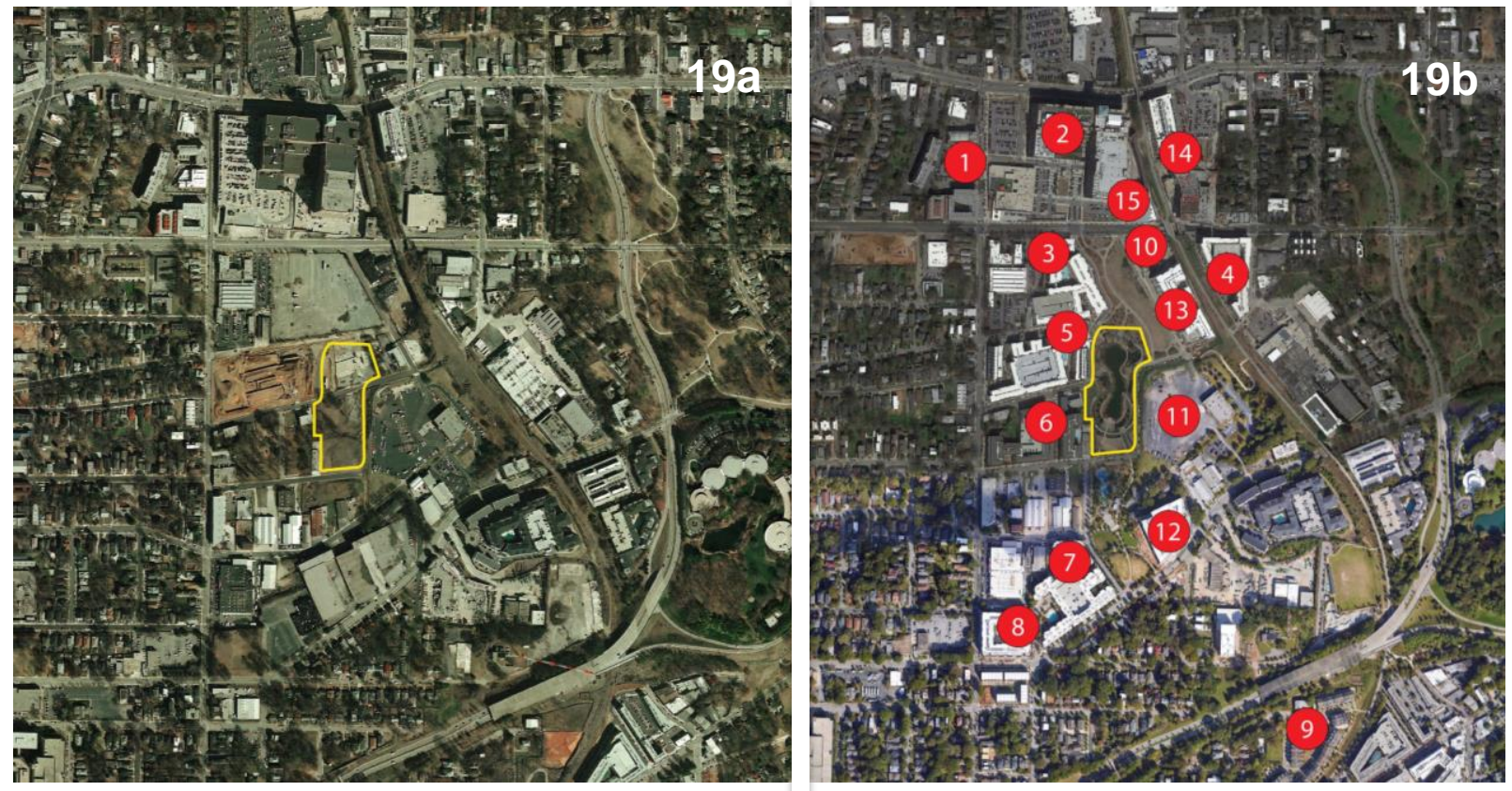

Figure 21a. 2008 Old Fourth Ward development prior to Historic Fourth Ward Park construction. Google Earth V 7.3.1.4507. Fulton County, GA, USA. 33.7694 N, 84.3648 W. Google Imagery 2018, TerraMetrics, 2018. (Accessed July 5, 2018).

Figure 21b. Economic impact map (2018). Adapted from a map provided by the Atlanta Beltline Inc. and the Department of Watershed Management.

Figure 21b shows the some of the primary new development in Old Fourth Ward after the construction of the park. Figure 21a shows the area in 2008 as a comparison.

Map Key

AP: Apartments

RT: Retail

CD: Condos/Townhomes 
OF: Office

1. Troy-Peerless Lofts (CD)

2. Ponce City Market (AP/CD/RT/OF)

3. 641 North Ave NE (AP)

4. Perennial Apartments (AP)

5. AMLI The Fourth (AP)

6. Camden Fourth Ward Apartments (AP)

7. AMLI Six60 (AP)

8. 608 Ralph McGill Blvd (AP)

9. Minerva Townhomes on Highland (CD)

10. The Mill (OF)

11. 760 Ralph McGill (AP)

12. Anthem on Ashley Apartments (AP)

13. North \& Line (AP/RT)

14. Kroger (RT)

15. The Plaza at North Avenue

Source: Adapted from map provided by Atlanta BeltLine Inc and the Department of Watershed Management.

\section{Calculations:}

Total construction costs of developments in the area include two billion dollars' worth of investment and one billion dollars' investment in the near future. The future investment dollars are based on New City's predictions of their own future developments and known future developments from other developers.

\section{Sources:}

Clark, Jay. 2018. Interview with Rachael Shields. July 2.

Irwin, Jim. 2018. Interview with Rachael Shields. June 26.

Munger, Richard. 2018. Interview with Rachael Shields. July 24.

\section{Limitations:}

Figure $21 \mathrm{~b}$ includes as many development projects that were known to the research team, but there are likely more not included on the map. The developer provided the investment dollar numbers, and they were not independently verified by the research team.

- Contributed to a $60 \%$ increase in the number of occupied housing units in the surrounding census tract from 2009 to 2016, compared to an 8\% increase for all of Fulton County. 


\section{Methods:}

The U.S. Census Bureau American Fact Finder was used to access census and American Community Survey data before and after the construction of the park (United States Census Bureau) from 2009 and 2016. The American Community Survey produces population, demographic, and housing unit estimates (American Community Survey). For comparison, the census tract 17 and Fulton County occupied housing units, vacancy rates, and population were compiled.

\section{Calculations:}

Occupied Housing Units

Occupied Housing Units Census Tract 17:

Occupied Housing Units (2009): 1,327

Occupied Housing Units (2016): 2,119

Amount of Change: +792

Percent Change Calculation: $((2,119-1,327) / 1,327)^{\star} 100$

Percent Change: $+59.68 \%$

Occupied Housing Units Fulton County:

Occupied Housing Units (2009): 355,452

Occupied Housing Units (2016): 385,103

Amount of Change: $+29,651$

Percent Change Calculation: $((385,103-355,452) / 355,452) * 100$

Percent Change: $+8.34 \%$

\section{Additional Information:}

\section{Number of Vacancies}

\begin{tabular}{|l|r|r|}
\hline \multirow{2}{*}{ Total: } & \multicolumn{2}{|c|}{ Census Tract 17, Fulton County, Georgia } \\
\cline { 2 - 3 } For rent & Estimate & Margin of Error \\
\hline Rented, not occupied & 397 & $+/-128$ \\
\hline For sale only & 172 & $+/-88$ \\
\hline Sold, not occupied & 25 & $+/-41$ \\
\hline For seasonal, recreational, or occasional use & 52 & $+/-59$ \\
\hline For migrant workers & 0 & $+/-132$ \\
\hline Other vacant & 11 & $+/-18$ \\
\hline
\end{tabular}

Figure 22. 2009 vacancies for census tract 17. Source: American Community Survey

\begin{tabular}{|l|r|r|}
\hline \multirow{2}{*}{ Total: } & \multicolumn{2}{|c|}{ Census Tract 17, Fulton County, Georgia } \\
\cline { 2 - 3 } & Estimate & Margin of Error \\
\hline For rent & 276 & $+/-117$ \\
\hline Rented, not occupied & 134 & $+/-90$ \\
\hline For sale only & 62 & $+/-74$ \\
\hline Sold, not occupied & 20 & $+/-33$ \\
\hline For seasonal, recreational, or occasional use & 44 & $+/-53$ \\
\hline For migrant workers & 0 & $+/-13$ \\
\hline Other vacant & 0 & $+/-13$ \\
\hline
\end{tabular}

Figure 23. 2016 vacancies for census tract 17. Source: American Community Survey 


\begin{tabular}{|l|r|r|}
\hline \multirow{2}{*}{ Total: } & \multicolumn{2}{|c|}{ Fulton County, Georgia } \\
\cline { 2 - 3 } & Estimate & Margin of Error \\
\hline For rent & 70,469 & $+/-2,084$ \\
\hline Rented, not occupied & 26,747 & $+/-1,261$ \\
\hline For sale only & 2,761 & $+/-520$ \\
\hline Sold, not occupied & 14,385 & $+/-1,204$ \\
\hline For seasonal, recreational, or occasional use & 3,448 & $+/-542$ \\
\hline For migrant workers & 2,320 & $+/-418$ \\
\hline Other vacant & 72 & $+/-72$ \\
\hline
\end{tabular}

Figure 24. 2009 vacancies for Fulton County. Source: American Community Survey

\begin{tabular}{|l|r|r|}
\hline \multirow{2}{*}{ Total: } & \multicolumn{2}{|c|}{ Fulton County, Georgia } \\
\cline { 2 - 3 } & Estimate & Margin of Error \\
\hline For rent & 64,830 & $+/-1,920$ \\
\hline Rented, not occupied & 16,911 & $+/-1,166$ \\
\hline For sale only & 4,464 & $+/-609$ \\
\hline Sold, not occupied & 5,511 & $+/-665$ \\
\hline For seasonal, recreational, or occasional use & 3,373 & $+/-463$ \\
\hline For migrant workers & 7,089 & $+/-740$ \\
\hline Other vacant & 86 & $+/-67$ \\
\hline
\end{tabular}

Figure 25. 2016 vacancies for Fulton County. Source: American Community Survey

Vacancies Census Tract 17:

Vacancies (2009): 397

Vacancies (2016): 276

Amount of Change: -121

Percent Change Calculation: $((276-397) / 397){ }^{*} 100$

Percent Change: $-30.48 \%$

Vacancies Fulton County:

Vacancies (2009): 70,469

Vacancies (2016): 64,830

Amount of Change: $-5,639$

Percent Change Calculation: $((64,830-70,469) / 70,469) * 100$

Percent Change: $-8 \%$

Population

Population Census Tract 17:

Population (2009): 2,553

Population (2016): 4,278

Amount of Change: $+1,725$

Percent Change Calculation: $((4,278-2,553) / 2,553)^{\star} 100$

Percent Change: $+67.57 \%$

Population Fulton County:

Population (2009): 886,982 
Population (2016): 996,757

Amount of Change: $+109,775$

Percent Change Calculation: $((996,757-886,982) / 886,982) * 100$

Percent Change: $+12.38 \%$

\section{Sources:}

American Community Survey. United States Census Bureau - American Fact Finder. Accessed July 2, 2018. https://factfinder.census.gov

United States Census Bureau - American Fact Finder. Accessed July 2, 2018.

https://factfinder.census.gov

\section{Limitations:}

The most recent data available for occupied housing units came from 2016; this included renter occupied housing units, vacancy rates, and population. While 2009 was not the earliest available data, earlier data would have more heavily reflected the impact of the financial crisis of 2008.

\section{Cost Comparison Methods}

- The district's combined sewer overflow problem could have been solved with a traditional gray solution like new sewer tunnels with an estimated cost of $\$ 70$ million, but local advocates campaigned for the less expensive \$23-million Historic Fourth Ward Park. The park manages nearly the same amount of water as the proposed sewer tunnels, released the city from the consent decree from the U.S. Environmental Protection agency, and saved the City approximately $\$ 50$ million dollars while providing multiple additional benefits.

\section{Sources:}

City of Atlanta Department of Watershed Management and HDR. Atlanta's Historic Fourth Ward Park: An Integrated Recreational Stormwater Solution. 


\section{Appendix A \\ Qualtrics Survey}

\section{LAF Outdoor Space Evaluation}

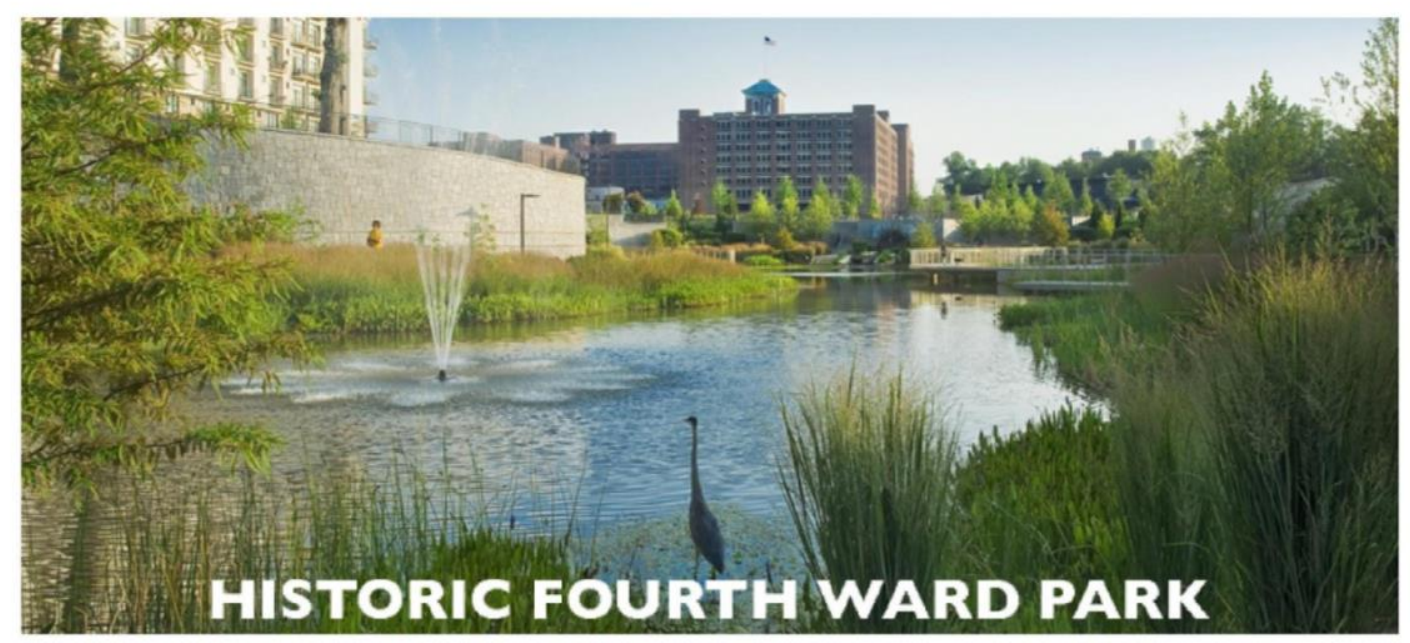

Consent Letter

$4 / 23 / 2018$

Dear Outdoor Space User:

Your input on this outdoor space is important to research we are conducting. I am a graduate student under the direction of Dr. Jon Calabria in the College of Environment and Design at The University of Georgia. I invite you to participate in a research study entitled LAF Outdoor Space Evaluation that is being conducted under the auspices of Landscape Architecture Foundation to understand your perception of this space. You must be 18 years of age or older to participate.

Your participation will involve taking a questionnaire that may take about 10 minutes. Your involvement in the study is voluntary, and you may choose not to participate or to stop at any time without penalty or loss of benefits to which you are otherwise entitled. If you decide to stop or withdraw from the study, the information/data collected from or about you up to the 
point of your withdrawal will be kept as part of the study and may continue to be analyzed. Your data is confidential and only researchers will have access to data stored on password protected devices. The results of the research study may be published, but your name or any identifying information will not be used. In fact, the published results will be presented in summary form only.

The findings from this project may provide information on how you and others perceive this space. There are no known risks or discomforts associated with this research.

If you have any questions about this research project, please feel free to contact me at 706-542-1816 or send an e-mail to rachael.shields@uga.edu. Questions or concerns about your rights as a research participant should be directed to The Chairperson, University of Georgia Institutional Review Board; telephone (706) 542-3199; email address irb@uga.edu. By checking the box below, you are agreeing to participate in the above described research project. Thank you for your consideration and providing your insight on this outdoor space. Please keep this letter for your records. Sincerely,

Rachael Shields

Agree and continue Disagree

O

STEP 1: Think about the outdoor area you are in - First, decide on the boundaries of the outdoor space to be evaluated. (Include everything that is viewable, even if beyond the space itself.)

STEP 2: Walk and sit in the area - Walk around slowly, test any furniture, look at the area from different positions.

STEP 3: Please tell how you feel in this space

Do you spend time here with others or alone? 

Alone
With 1 or 2 Others
With Larger Groups
$\mathrm{O}$
$\mathrm{O}$
$\mathrm{O}$

How often do you come here each week?

$\begin{array}{ccc}\text { Daily } & 2-4 \text { Times } & 1 \text { or Less } \\ 0 & 0 & 0\end{array}$

How much time do you spend here each week?

More than 1 hour

O
30 minutes to 1 hour

$\mathrm{O}$
Less than 30 minutes

$\mathrm{O}$

For the next four questions, please provide just two or three key words in each case

What attracts you to this place?

What types of things do you do in this place?

What do you like about this place? 
What would make this place more inviting for you?

For these questions, please indicate whether you agree or disagree with the statement.

\begin{tabular}{|c|c|c|c|c|c|}
\hline & $\begin{array}{l}\text { Strongly } \\
\text { Agree }\end{array}$ & Agree & Neutral & Disagree & $\begin{array}{l}\text { Strongly } \\
\text { Disagree }\end{array}$ \\
\hline I avoid this place & 0 & $\mathrm{O}$ & 0 & $\mathrm{O}$ & 0 \\
\hline $\begin{array}{l}\text { This outdoor area } \\
\text { provides a real sense of } \\
\text { escape and relief from } \\
\text { being indoors }\end{array}$ & $\mathrm{O}$ & 0 & $\mathrm{O}$ & $\mathrm{O}$ & O \\
\hline $\begin{array}{l}\text { This is a good place to } \\
\text { hang out }\end{array}$ & $\mathrm{O}$ & 0 & 0 & O & 0 \\
\hline I feel safe in this place & $\mathrm{O}$ & 0 & 0 & $\mathrm{O}$ & 0 \\
\hline $\begin{array}{l}\text { This a good place to read } \\
\text { or study }\end{array}$ & $\mathrm{O}$ & $\mathrm{O}$ & $\mathrm{O}$ & $\mathrm{O}$ & $\mathrm{O}$ \\
\hline $\begin{array}{l}\text { This place discourages } \\
\text { interaction with others }\end{array}$ & 0 & 0 & 0 & 0 & 0 \\
\hline
\end{tabular}

STEP 4: Please evaluate the area

for these questions, please indicate whether you agree or disagree with the statement 
From this area, you can watch

human activities, nearby streets and traffic

There is a diverse mix of trees, vines, flowers and shrubs that attract

wildlife

There are at least one or more choices of private outdoor places to sit

This area includes abundant healthy green plants (vs. large areas of paving)

The area is overall fairly quiet, and free from obnoxious noises

There are sidewalks partly or fully shaded from mid-day or hot afternoon sun

There are enough tables for reading, working, and eating

Seating surfaces are comfortably shaped and of materials that do not get too hot or cold

Paving is level, smooth, no deep cracks, and with handrails where needed

There are nearby restrooms, with access to a drinking fountain

There is plenty of seating available with choices to sit in sun or shade

This outdoor space can be easily viewed and reached from well-used indoor spaces
Strongly

Agree

O

$\mathrm{O}$

O

O

O

O

O

O

O

O

O

O

O

O

O

0

0

0

O

0

0

O
Agree

Neutral

Disagree

Strongly

Disagree

O

O

$\mathrm{O}$

O

O

O

O

O

0

O

0

O

O

O

O

O

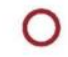

O 
There are paths or sidewalks of different lengths

$\begin{array}{lllll}0 & 0 & 0 & 0 & 0 \\ 0 & 0 & 0 & 0 & 0 \\ 0 & 0 & 0 & 0 & 0\end{array}$
linger to meet or greet people

STEP 5: Please tell us about yourself

What is your age? (in years)

$+2$

What gender do you identify with?

Male

O Female

Other

I identify my ethnicity as:
Asian
Olack/African 


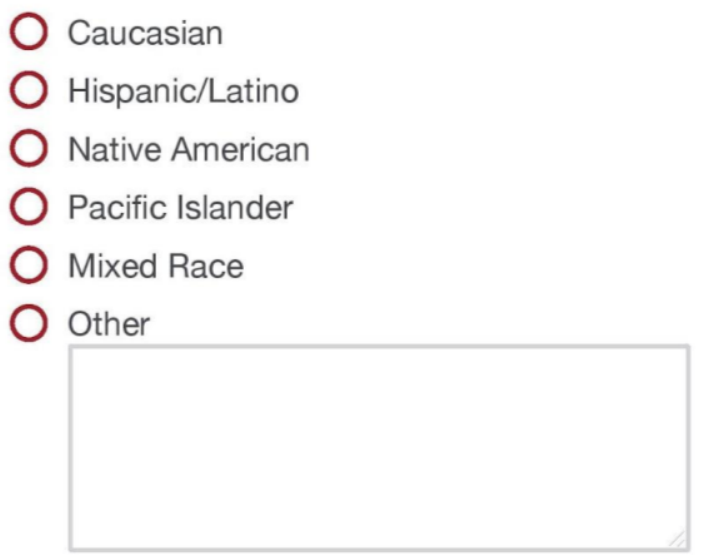

What is the highest level of education you have completed?
Did not finish high school
O High school or GED
Attended college but no degree
Associate's or vocational degree
College bachelor's degree
Some graduate work
$\mathrm{O}$ Graduate degree, Masters or $\mathrm{PhD}$

What is the zip code of your primary residence?

Is there anything else you'd like to share about your experience in this space?

THANK YOU for helping us with this survey - please contact us at Rachael.Shields@uga.edu with any questions.

C2018, Orland, Calabria, Shields, Vick, College of Environment and Design, University of Georgia, Athens, GA. Adapted from: (C2014, Susan Rodiek, Center for Health Systems \& Design, Texas A\&M University, College Station, TX. AND OLIN and Partners, Washington Canal Park Post-Occupancy Evaluation IRB: 